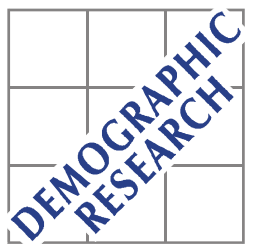

Demographic Research a free, expedited, online journal

of peer-reviewed research and commentary in the population sciences published by the Max Planck Institute for Demographic Research

Konrad-Zuse Str. 1, D-18057 Rostock · GERMANY

www.demographic-research.org

DEMOGRAPHIC RESEARCH

VOLUME 17 ARTICLE 10, PAGES 247-300

PUBLISHED 16 NOVEMBER 2007

http://www.demographic-research.org/Volumes/Vol17/10/

DOI: 10.4054/DemRes.2007.17.10

Research Article

First union formation in Estonia, Latvia, and Lithuania:

Patterns across countries and gender

Kalev Katus

Allan Puur

Asta Põldma

Luule Sakkeus

(C) 2007 Katus et al.

This open-access work is published under the terms of the Creative Commons Attribution NonCommercial License 2.0 Germany, which permits use, reproduction \& distribution in any medium for non-commercial purposes, provided the original author(s) and source are given credit. See http:// creativecommons.org/licenses/by-nc/2.0/de/ 


\section{Table of Contents}

1 Introduction $\quad 248$

2 Theoretical considerations 250

3 The comparative setting 252

$4 \quad$ Data and analytical approach $\quad 256$

$\begin{array}{lll}4.1 & \text { Trends in first union formation } & 259\end{array}$

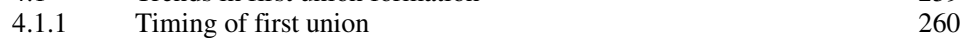

4.1.2 Mode of union formation 267

4.2 Modelling the gender difference in union formation 272

4.2.1 Variables, hypotheses and operationalisation 273

$\begin{array}{lll}\text { 4.2.2 Modelling results } & 278\end{array}$

$5 \quad$ Summary and discussion of the findings 282

$\begin{array}{lll}6 & \text { Acknowledgements } & 287\end{array}$

$\begin{array}{ll}\text { References } & 288\end{array}$

$\begin{array}{ll}\text { Appendix } & 297\end{array}$ 


\title{
First union formation in Estonia, Latvia, and Lithuania: Patterns across countries and gender
}

\author{
Kalev Katus ${ }^{1}$ \\ Allan Puur ${ }^{2}$ \\ Asta Põldma ${ }^{3}$ \\ Luule Sakkeus $^{4}$
}

\begin{abstract}
This article examines the changes in first union formation in the Baltic countries between the late 1960s and early 1990s, in the context of societal and family-level gender relations. The analyses are conducted using microdata from the European Family and Fertility Surveys program. Our results indicate that in Estonia and Latvia the shift from direct marriage to cohabitation started well before the fall of socialist regime. Event-history models provide support for a hypothesised association between union formation and gender systems, with Lithuania showing more traditional features in both respects, possibly due to long-standing cultural differences between the countries.
\end{abstract}

\footnotetext{
${ }^{1}$ Estonian Interuniversity Population Research Centre, P.O.Box. 3012, Tallinn 10504 Estonia. E-mail:kalev@ekdk.estnet.ee

${ }^{2}$ Estonian Interuniversity Population Research Centre, P.O.Box. 3012, Tallinn 10504 Estonia. Phone: +3726454125 Fax: +372 6604198. E-mail: allan@ekdk.estnet.ee

${ }^{3}$ Estonian Interuniversity Population Research Centre, P.O.Box. 3012, Tallinn 10504 Estonia. E-mail: asta@ekdk.estnet.ee

${ }^{4}$ Estonian Interuniversity Population Research Centre/Ministry for Social Affairs, P.O.Box. 3012, Tallinn 10504 Estonia. E-mail: luule@ekdk.estnet.ee.
} 


\section{Introduction}

For several decades statistics have documented the salient transformation of family patterns in industrialised countries. Marriage rates have decreased and consensual unions have increased considerably, fertility has reached low or even very low levels, family formation comes later in life, and marriage has started to lose its hegemony as a dominant context for childbearing. These developments have occurred in parallel with profound changes in the roles of men and women, as reflected in parity in educational attainment and the closing gap in the level of workforce participation. Over the same period ideational change has resulted in an adjustment in people's attitudes towards a greater acceptance of new behaviours.

The observable synchronicity of these trends has given rise to research focusing on the relationship between the change in family and fertility patterns on the one hand, and gender roles on the other. The explanatory framework in this research originates in economic theories that predicted largely negative consequences of women's increased independence for the family (Becker 1981; Ermisch 1996). Based on the assumption of the male breadwinner family model the economic paradigm, however, failed to incorporate the varying context in which family formation decisions are made. In this respect, recent research has drawn attention to the role of societal and family level gender relations that are likely to influence the mechanisms between the participation of women and men in education and employment, and family formation (Chesnais 1996; Mason 1997; 2001; McDonald 2000; 2002). Evidence from a number of studies has shown that the impact of educational attainment and labour force participation on family formation depends on the degree of compatibility between these life domains, observed at societal and individual, structural and cultural levels (e.g. Blossfeld 1995; Blossfeld et al 2005; Corjin and Klijzing 2001).

This article seeks to complement the referred body of comparative research on family initiation behaviour by analysing first union formation in the three Baltic countries. The main objective is to analyse the patterns of entry into the first conjugal union in Estonia, Latvia and Lithuania, in the context of transforming gender relations. To ascertain the influence of the gender system, the study focuses on education and labour force participation, which are known to indicate the prevailing division of responsibilities between men and women. Although there are detailed studies published on individual countries (e.g. Katus, Puur and Põldma 2002; Stankuniene 1997; Vikat 1994; Zvidrins and Ezera 1999), cross-country research focusing on family formation in the Baltic region appears scarce. Therefore the article also aims to fill one of the current gaps in the geography of comparative family studies.

The study employs microdata from national surveys conducted in the framework of the European Family and Fertility Surveys programme. Partnership histories of birth 
cohorts from 1945 to 1973, that are available for all three countries, provide an insight into the development of union formation from the late 1960s until the mid-1990s. For Estonia, Latvia and Lithuania, this timeframe corresponds to the later decades of state socialism, moulded according to the Soviet model $^{5}$. In this respect, the results are expected to complement the evidence pertaining to similar societal regimes that has become available for other countries of the former Eastern bloc, including East Germany, the Czech Republic, Hungary and Poland (e.g. Kantorova 2004; 2006; Kreyenfeld 2006; Olah and Fratzcak 2003; Robert and Bukodi 2005; Speder 2005).

A particular interest in studying family formation in the Baltic countries in comparative perspective stems from the similarity of the institutional settings that prevailed in all three countries over a long period of time. From an analytical point of view, this situation provides an opportunity to contrast the influence of institutional factors with long-standing cultural differences and previous family/population dynamics. Along these lines, the invariability of the patterns between the countries would imply that gender relations are predominantly shaped by society's institutional framework, whereas dissimilar patterns would lend support to the fundamental importance of cultural influences. Furthermore, an answer to this question will help us to understand the re-emerging demographic diversity in the region during the past decade, and the reasons why shifts in family formation and fertility, interlinked in the concept of the second demographic transition (Lesthaeghe and Van de Kaa 1986; Van de Kaa 1987), are manifested to a noticeably different extent in the Baltic countries.

To address these issues, the paper is structured in six sections. Following the introduction, the second section starts with a brief discussion of theoretical considerations, which highlights the relationship between family formation and gender systems. The next section describes the contextual similarities and dissimilarities between the Baltic countries, relevant for the analysis of family patterns. The fourth section describes the data and explains the analytical approach employed. The fifth section presents the empirical findings, obtained by means of both descriptive techniques and multivariate event-history models. The concluding section presents the summary and a discussion of the findings.

\footnotetext{
${ }^{5}$ The change of the regime is also captured by the data, however, due to censoring analysis of transformed family initiation patterns since 1990 should be postponed until a new round of comparative surveys in the framework of Gender and Generations Programme becomes available.
} 


\section{Theoretical considerations}

Perhaps the most frequent starting point for the explanation of nuptiality trends in industrialised countries relates to micro-economic theory, which attributes the decrease in marriage and parenthood to the change in gender roles, in particular to the increased economic independence of women. As argued by Becker in his influential work, "A Treatise of the Family", growing educational attainment and labour force participation have reduced women's incentives to marry and have children (1991).

The logic behind Becker's argument is that as women receive education on an equal footing with men and an have access to improved opportunities in the labour market, the economic gains from marriage tend to become less significant. With decreased specialisation in housework skills, women are no longer dependent on their partners' economic performance and can earn a living on their own. In addition, the opportunity costs of time spent on the family are also seen to increase with the accumulation of human capital, via foregone earnings and slower progress in terms of career advancement. In the micro-economic framework these mechanisms have led to the formulation of an economic independence hypothesis according to which better education and stronger attachment to the labour market among women would translate into a lower propensity to form a union. In a broader view, the same reasoning has been extended to childbearing and union dissolution (e.g. Cigno 1991; Ermish 1996; Gustafsson and Kalwij 2006).

Among men, on the other hand, the New Home Economics posits an opposite outcome. With reference to settings with a more or less complete role specialisation, family formation will interfere little with men's role as the main provider of family income. This makes men with a higher earning capacity more attractive as potential partners and leads to the expectation of positive effects of educational attainment and established labour market position on family formation, be it conjugal union or parenthood.

Despite its relatively wide appeal, however, the independence hypothesis has proven controversial from both theoretical and empirical points of view. In contrast to economic reasoning emphasising the negative impact of overlapping gender roles, Oppenheimer (1994) has shown that women's employment may in fact increase rather than reduce the benefits for a family unit. With two earners the family becomes less vulnerable to risks if one partner is unable to provide his/her contribution. If this is true, high-earning women should be particularly attractive partners. With respect to the timing of union formation, Oppenheimer pointed out that women's economic independence could even facilitate earlier entry into marriage since it would take longer for young men as single earners to be able to support the family, especially when the labour market situation was less advantageous and involved greater uncertainty than in 
the past. Also, both men and women being enrolled in advanced education and being economically active, have opportunities to meet a larger number of individuals with similar interests, and the extended social networks can reduce the time it takes to locate an eligible partner. From this perspective, women's education and employment can be viewed as a highly adaptive strategy in modern society, rather than a threat to the family as a social institution.

From a complementary angle, researchers (e.g. Lesthaeghe 1983; Mason and Jensen 1995) have called attention to the overly static view of the micro-economic theory - in particular, it tends to conceptualise social processes as resulting from the decision-making of atomised individuals, operating under the traditional male breadwinner model ${ }^{6}$. In doing so, the micro-economic approach effectively fails to recognise that the terms upon which the costs and benefits of family formation are evaluated are not fixed but subject to change across time and space. Women's increased independence and the change in gender roles may lead partners to de-emphasise the division of labour as the potential source of satisfaction, instead emphasising other aspects of partnership (quality of emotional companionship, sexual satisfaction, etc). This helps to understand why the economic independence hypothesis has lacked strong empirical support. The findings pertaining to a number of micro-level studies show that not only the strength but also the direction of the effects of educational attainment and labour market attachment on union formation have been found to vary from one country to another (reviews by Santow and Bracher 1997; Liefbroer and Corijn 1999; Billari and Philipov 2003). By the same token, a case can also be made for substantial variation of these effects within countries, for example by birth cohort and age.

Following the arguments above, our theoretical point of departure in this article is that family formation is linked in a complex set of relations to to other factors, among which the significance of the gender context has become increasingly recognised during the past decade. Mason $(1997 ; 2001)$ has defined gender system as a set of socially constructed beliefs, norms and common practices for male and female behaviour that are found, in a variable form, in every society. It follows that when individuals and institutions operate on the basis of an assumption that men should engage in full-time labour market activity and women primarily in housework, we can say that there is a high degree of gender role differentiation. Under such a system, it is evidently more difficult for women to reconcile the demands of family life and labour market career and one can expect negative association between education, employment, and family

\footnotetext{
${ }^{6}$ In the context of contemporary developments, the male breadwinner model is frequently labelled as 'traditional', as opposed to 'modern' dual earner family. However, historical research in family models has pointed to the fact that the development towards symmetrical roles can be regarded, to an important extent, as a return to the pre-industrial model. In long-term perspective, the single (male) breadwinner family constitutes a relatively recent invention which enjoyed popularity in industrialised countries during a relatively short timespan in the late 19th and 20th century (Davis 1984; Pott-Butter 1993).
} 
formation. Conversely, egalitarian gender relations are seen to reduce the conflict between competing demands and to facilitate the combination of career and family responsibilities. The empirical evidence in support of these theses has been quite strong in comparative studies of family formation (e.g. Blossfeld 1995, Blossfeld et al 2005; Corijn and Klijzing 2001). The higher the dominance of gender equality as a cultural value within society, and the better the structural opportunities for female employment, the less polarised is the impact of educational attainment and labour force participation between men and women.

This article confronts the above described theoretical perspectives with evidence from the Baltic region at the later stage of state socialism. We focus on the patterns of union formation among men and women, and hypothesise the presence of systematic differences across countries. Ascertaining these differences will lead to questions about their origin and a plausible link to the gender context, the specific hypotheses being discussed in the following sections. To set the stage for the analysis, the next section briefly outlines some general features of the demographic, economic and cultural backgrounds of the countries that are relevant to the analysis of family formation.

\section{The comparative setting}

The Baltic countries are neighbours that share a number of commonalities, which have been strengthened by a broadly similar history during the 20th century. At the same time, the previous experiences of these nations differed and many of these differences remain salient today. Therefore it is advisable to start with some demographic history. ${ }^{7}$

In terms of nuptiality, Estonia, Latvia and Lithuania historically fell within the area of the West European marriage pattern (Hajnal 1965). This pattern of relatively late marriage, with a remarkably high proportion of population never marrying, became established in the region by the 18th century and persisted until the Second World War. Leaving aside Ingria, which was inhabited by Finno-Ugrians but re-populated after the establishment of St. Petersburg, the Baltic countries and Finland formed the northern boundary of the European marriage pattern (Sklar 1974; Palli 2004).

The dynamics of fertility transition, which resulted in a shift to the modern regime of population reproduction, has been comprehensively studied within the framework of the Princeton European Fertility project (Coale and Watkins 1986). Nuptiality and fertility indices derived from the Princeton project indicate that the transition progressed

\footnotetext{
${ }^{7}$ Treatments that comprehensively and comparatively cover the development of all three Baltic countries have been relatively few. For international readers, reference to works by Rei (1970), von Rauch (1974), and Misiunas and Taagepera (1993) published beyond the Iron Curtain can be given. A recent survey of economic history is available from Kahk and Tarvel (1997).
} 
with varying pace in the Baltic region. In Estonia and Latvia, the onset of fertility transition dates back to the mid-19th century, and judging by the spread of parityspecific family limitation and related characteristics, the emergence of modern population reproduction in Estonia and Latvia was the earliest among the nations included in the Russian Empire and synchronous with the pioneering nations of fertility transition in Northern and Western Europe (Coale, Anderson and Härm 1979; Katus 1994; 1997). With respect to Lithuania, the demographic transition commenced several decades later but progressed rapidly from the beginning of the $20^{\text {th }}$ century.

The simultaneous collapse of the Russian and German Empires during the First World War presented an opportunity for the Baltic peoples to build their nation states. With respect to the demographic regime, Estonia and Latvia were already approaching underreplacement fertility and slow alteration of generations in the late 1920s, while in Lithuania, the fertility decline associated with demographic transition was well in progress. A very similar pattern, with the two northern neighbours being more advanced, occurred in the timing of social and economic modernisation (Kahk and Tarvel 1997; Mitchell 2003). The provinces of Estland, Livland and Kurland - that were later to become Estonia and Latvia - were the first regions of the Russian Empire to abolish serfdom, and their lead was extended into the 20th century in many commonly reported indicators, such as the proportion of urban population, literacy rate, number of students, structure of employment, general living standard, circulation of newspapers, etc. Within the Baltoscandian region Estonia and Latvia came relatively close to Finland in terms of socio-economic development in the late 1930s while Lithuania was lagging behind (Lugus and Vartia 1993; Valge 2003).

The Second World War left the Baltic countries under Soviet occupation, which lasted for almost fifty years. The new regime introduced a rearrangement of the entire societal organisation by means of force, terror and mass deportations. ${ }^{8}$ In the early postwar decades demographic differences were still quite extensive, however, fertility and mortality levels moved gradually towards convergence. In Estonia and Latvia fertility stayed remarkably low (under replacement) in the 1950s and 1960s as both countries failed to experience a postwar baby boom, unlike other nations that had experienced low fertility in the prewar years (Calot and Sardon 1997; Festy 1984). In the late 1960 s, contrary to the general trend in demographically advanced countries, Estonian and to a somewhat lesser extent Latvian fertility, increased and stayed close to

\footnotetext{
${ }^{8}$ The combined human losses resulting from war and its aftermath were extensive in all three countries, estimated at levels above 30 per cent (Misiunas and Taagepera 1993). As the countries had reached different stages of demographic development by that period, the long-term consequences of these losses appear rather dissimilar. Disregarding the direct and indirect effects of immigration, Estonia and Latvia are among the few countries in Europe where the prewar population level has not been reached. In the case of Lithuania, relatively rapid population growth supported the replacement of losses resulting in a population size in excess of the prewar number.
} 
replacement until the turn of the 1990s. In Lithuania, the period following WWII was marked by a more or less continuous decline in fertility until the late 1970s. In the 1980s Lithuania's fertility level increased somewhat but more importantly, for the first time since the onset of demographic transition, the level converged with that of Estonia and Latvia. The trends in union formation during this period are discussed in detail in the following sections of the article.

Turning to institutional frameworks in the postwar decades, the convergence between the Baltic countries appeared strong and steep - from the outset the Soviet authorities followed a strategy of far-reaching centralisation and the introduction of uniform models in virtually all fields of administration. ${ }^{9}$ The application of these uniform models applied to the structures that framed daily living and the life courses of the population, including the functioning of the labour market and economy in general, the organisation of educational system, the allocation of housing, health care and social protection, pension schemes, etc (Mertelsmann 2003).

The high degree of uniformity also extended to the societal gender system, in which respect Estonia, Latvia and Lithuania shared the characteristics that are generally associated with state socialist regimes throughout Central and Eastern Europe. By the 1950s women in the Baltic region were already demonstrating a very high attachment to the labour force. In international comparison the Baltic countries ranked top with respect to female employment, and women were overwhelmingly to be found in fulltime jobs (Puur 1995; 2000). As elsewhere in the CEE countries, employment was defined as a state-guaranteed social right but at the same time, it was regarded as a societal obligation for all able-bodied citizens, be they men or women. Consequently, the proportion of women who chose to become full-time housewives after marriage or childbirth was very small and the dual-earner family model clearly prevailed in all three countries. In the 1970s and 1980s, the gender gap in economic activity was almost entirely attributable to women who were currently on maternity and childcare leave.

From the economic point of view, the dual-earner family model was supported by a low level of administratively determined wages, which made it difficult for most families to cope on a single income. Yet another factor that contributed to the convergence of labour force participation between men and women, and to the gender equality in societal institutions in general, was the growth in female educational attainment. According to census data, in all three countries the previously existing gender gap in tertiary education was closed in the cohorts born in the early 1940s, who completed their studies in the 1960s. In subsequent generations the proportion of university graduates appeared systematically higher among women, with the female

\footnotetext{
${ }^{9}$ In terms of the legal framework, for example, the norms of the Russian Federation were enforced in the 1940s-1950s. Later the so-called republican regulations were introduced, however, their country specifity was limited to details of secondary and tertiary importance (Katus, Puur and Põldma 2004).
} 
advantage expanding towards younger generations. An identical pattern - women having higher educational attainment than men - is also characteristic of the level of secondary education where a reversed gender gap can be traced back to the birth cohorts of the 1930s. Furthermore, owing to the unified model of a centrally planned education system, the proportions of people who attained secondary and tertiary education were very similar between Estonia, Latvia and Lithuania in the cohorts covered by this study. ${ }^{10}$

The societal gender context also included various provisions designed to promote the dual earner family model and facilitate the reconciliation between women's employment and family responsibilities. A central element in this field was public childcare, which started to develop rapidly in the 1960s and in the following decades service provision in the Baltic region reached levels comparable to Hungary and the Czech Republic (Stankuniene 1991; UNICEF 1999). Schemes for the care of very young children also followed the same model in all three countries. Other familyfriendly provisions were relatively limited during the early postwar decades but were gradually extended. Beginning in 1968 women were entitled to take unpaid leave until the child's first birthday, without losing their jobs and maintaining an uninterrupted employment record. Further extension of provisions came in 1981 when the duration of partly paid leave (at a relatively low flat rate of benefits) was extended to one year, and unpaid leave to 18 months. On the eve of societal transition, all three countries introduced an additional extension that allowed mothers to stay on leave until the child's third birthday.

Against the background of relatively advanced gender equity in the public sphere, there is evidence that less progress was achieved in family-level gender relations. The results of sociological surveys conducted in the 1970s and 1980s point out that childrearing responsibilities were shared along traditional gender roles and the division of labour was such that housework was done mostly by women (Kelam 1986; Stankuniene et al 2003). In broad outline, these features held true throughout the Baltic region, however, differences in the methodology of the surveys prevents us from presenting comparable evidence for Estonia, Latvia and Lithuania. What also appears common for all three countries is that the division of roles in the domestic sphere along traditional lines was reinforced by several features of the institutional framework. For instance, the structure of administratively set wages indirectly favoured the sectors and occupations with a largely male workforce, consolidating the role of women as secondary earners. When the previous regulations were abolished, at the turn of the 1990s, the gender gap in wages decreased (Noorkõiv et al 1998). Eligibility for

\footnotetext{
${ }^{10}$ In tertiary education, this rapid expansion continued until the late 1960s. From that point on, however, the proportion of university graduates remained virtually unchanged for more than two decades.
} 
childcare leave was limited to mothers, which also supported the gender-specific division of roles in the private sphere.

Regarding the cultural dimension, the Baltic region is characterised by a longstanding divide between the Protestant (Lutheran) and Catholic domains. As is well known, Estonia belonged to the former, Lithuania represented the latter, and the territory of modern Latvia was split between the two influences - the provinces of Kurland and Livland became prevailingly Lutheran whereas Latgale, due to its association with Lithuania, maintained the Catholic tradition. Along with this divide, secularisation and related shifts in mentality commenced relatively early in Estonia and Latvia while in Lithuania the Church maintained its authority well into the postwar decades (Plaat 2003; Vardys 1990).

Turning to values, comparable data on Estonia, Latvia and Lithuania for the period addressed in this study is difficult to obtain. During the Soviet period, social research was kept under strict ideological censorship and apart from behavioural patterns the resultant information gap cannot be filled in by means of retrospective data collection. With respect to cultural differences we can refer to a comparative study by Mellens (1999) who performed an analysis of socio-economic and cultural diversity, which may be relevant from the demographic point of view, for more than thirty countries. Based on a broad set of variables, his conceptualisation of the cultural dimension included power distance, conservatism, gender equality, individualism and post-materialism. Along this dimension Estonia and Latvia were positioned as relatively close to the cluster of Nordic countries, while along the socio-economic dimension, the Baltic countries were clustered closely together. Although these findings are based on the data from the beginning of the 1990s, it might be assumed that due to the persistence of cultural characteristics, the validity of the observed pattern extends to the preceding decades.

We will return to these contextual differences and discuss their possible relationship to union formation in the concluding section.

\section{Data and analytical approach}

The data used in this paper come from national surveys carried out in Estonia, Latvia and Lithuania within the framework of the European Family and Fertility Surveys programme. The programme was coordinated by the United Nations Economic Commission for Europe and altogether covers 25 countries in the ECE region.

The surveys were based on the life course approach and contain full retrospective histories of partnership formation and dissolution, childbearing, educational and employment careers, and residential mobility. This survey design allows us to place 
family formation in a multidimensional biographical perspective, to unveil the interactions between the familial, educational, occupational and other facets of individuals' lives. A common core questionnaire applied in these national surveys and the conversion of microdata into a standardised format facilitates comparison between countries. Another important feature of the FFS programme, compared to its predecessors, relates to the fact that the data were collected for both women and men. From an analytical point of view, independent samples for women and men have permitted the incorporation of the gender dimension in a wide range of biographical analyses.

In all three Baltic countries, the FFS was the first survey to provide nationally representative event history data on the major life events of the population. The surveys were conducted over a relatively short time period around the middle of the 1990s. In Estonia, the data collection on women and men was split between a female survey conducted from January-November 1995 and a male survey with a time-lag of two years. The data for the Latvian survey were collected from September-October 1995, the fieldwork for the Lithuanian survey started in October 1994 and ended in December 1995. All countries used the random sampling method to draw representative probability samples, although the frame and specific procedures varied ${ }^{11}$. In Latvia and Lithuania, the survey covered the resident population in the currently fertile age span of 18-49 which translates into birth cohorts 1945-1977. In order to follow the developments over a longer run, the Estonian survey extended the range of the target population twenty years beyond the fertile age and covered the birth cohorts 1924-1973.

Following the general practice in the FFS programme, all three countries opted for proportionally larger samples for women. As a result, there are 5,021 female and 2,511 male respondents in the Estonian survey, the Latvian survey contains 2,699 female and 1,501 male respondents, and the Lithuanian survey resulted in 3,000 interviews with females and 2,000 interviews with male respondents. The response rate reveals an increase from south to north - in Lithuania 71 per cent of women and 66 per cent of men in the original sample were successfully interviewed, in Estonia the corresponding percentages amounted to 85 per cent for women and 81 per cent for men, leaving Latvia in the middle position (77 and 73 per cent respectively). A somewhat lower accuracy of the Lithuanian survey, relating to event dating and consistency with external sources, has also been observed in the data quality evaluations of the FFS programme (Festy and Prioux 2002; Klijzing and Cairns 2000).

\footnotetext{
${ }^{11}$ A concise description of the methodology of each survey, together with the overview of main findings and comparable standard tabulations is available from the country reports published by United Nations Economic Commission for Europe (UNECE 1998; 2000a; 2000b). A reference to national publications is included in the FFS website.
} 
The event of central interest in this study is the entry into a first conjugal union, whether by registered marriage or non-marital cohabitation where partners commence shared living in the same household. Within the life course framework, the first union marks perhaps one of the most important transitions made by men and women in their transition from adolescence to adulthood. Traditionally it was marriage that signalled the onset of family formation, and consequently, played the main institutional role for entry into parenthood. In the recent decades, however, this chain of events has transformed considerably with the increasing prevalence of non-marital cohabitation. To account for these developments and secure general comparability across countries and over time, the pathways of partnership formation are combined in this paper. A similar approach has been adopted in several recent studies, focusing on family formation in Eastern Europe (e.g. Billari and Philipov 2003; Kantorova 2004; Aassve, Billari and Speder 2006).

Another note refers to the definition of the working sample used throughout our study. To make the samples more homogeneous, we have restricted the analysis to the native population for all three countries. This leaves aside the immigrants who arrived in the Baltic countries after WWII, together with their second generation. Immigration started immediately after the return of the Soviets in 1944 and continued for more than four decades, resulting in an extensive shift in the population structure, particularly in the case of Estonia and Latvia (Sakkeus 2003). Judging by the ethnic composition, the proportion of non-titular nationalities reached the highest level in Latvia - in the first postwar census in 1959 the share of non-titular ethnic groups comprised 38 per cent of the population, by 1989 the corresponding proportion had almost reached parity (48 per cent) with Latvians. In Estonia, the 1959 census indicated the share of non-titular groups at 25 per cent, in 1989 it was close to 39 per cent. ${ }^{12}$ In Lithuania, the population composition was less affected by immigration and the proportion of Lithuanians kept close to the level of 80 percent.

The main reason for leaving the immigrant population aside relates to the demographic patterns that reflect population development in their regions of origin, in the Russian Federation and other parts of the former Soviet Union. Historically these areas did not share the experience of the West European marriage pattern and featured a noticeably later timing of demographic transition. Although these features relate to the past, analyses have shown that differences in behavioural patterns between the nativeand foreign-origin population persist, including family formation. Particularly in Estonia

\footnotetext{
${ }^{12}$ Although the corresponding Estonian figure was eight percentage points lower compared to Latvia in 1989, the change of the population composition had been more extensive in Estonia. In the course of WWII, Estonia lost four out of its five historical national minorities, and it has been estimated that by 1945 ethnic Estonians formed more than 97 per cent of the total population of the country. In Latvia and Lithuania, the proportion of the historical minority populations was higher, in both countries titular nationalities accounted for slightly more than 80 per cent after the war (Zvidrinsh 1995).
} 
and Latvia, the relative size of the foreign-origin populations renders the estimates for the total population an aggregate of rather divergent, sometimes contrasting elements ${ }^{13}$. The heterogeneity inherent in such estimates noticeably blurs the picture, particularly with respect to international comparisons. The specifity of demographic patterns among the foreign-origin population is discussed elsewhere (e.g. Katus, Puur and Sakkeus 2002; Sakkeus 2000, 2003).

In the following sections, the analysis of union formation is structured in two parts. In the first part, the cohort trends in the timing and the mode of union formation (direct marriage versus non-marital cohabitation) are examined by means of descriptive methods. In the second part, multivariate Cox regression models are applied to explore the influence of educational attainment and economic activity status, controlling for the effects of other factors, which are known to affect union formation. To reveal the variation in direction and strength of the relationship under interest, the analysis is country- and gender-specific throughout. In detail, the specification of models and covariates are discussed in the sections that follow.

\subsection{Trends in first union formation}

The presentation of the findings starts from a descriptive analysis which addresses the trends in the timing and type of first union. Together these two dimensions capture the major shifts that have occurred in behavioral patterns in the Baltic region over the past few decades, and allow a comparison with developments in other countries.

The analysis applies five-year birth cohorts and country as the main units. Cohort membership and country can be related to particular social and cultural contexts that people face while growing up and starting their adult lives. With respect to Estonia, the data permit us to follow the trends starting from the cohorts born in the mid-1920s until those born in the early 1970s, for Latvia and Lithuania the observation starts from the cohorts born in the second half of the 1940s. In terms of calendar time, these are the generations which represent nuptiality trends between the late 1960s (from the late 1940s in case of Estonia) and the early 1990s.

\footnotetext{
${ }^{13}$ Intermarriage has been relatively infrequent in the Baltic countries. In the Estonian FFS, 8.5 per cent of native respondents had a partner coming from a different ethnic background, and this proportion does not reveal signs of increase towards younger generations (Katus et al 2002). Judging from marriage statistics, in Lithuania the proportion of mixed marriages is below 10 per cent and 18-20 per cent in Latvia. As the FFS standard recode files did not include information about the country of origin or ethnicity of the partner, the analysis in the present article makes no distinction between respondents in homogeneous and mixed partnerships. The relatively small number of respondents in mixed partnerships ensures that their inclusion has no significant impact on the findings.
} 


\subsubsection{Timing of first union}

The panels of Figure 1 present entry into first union formation by means of survivorship functions, whether by marriage or non-marital cohabitation. Although the cohorts covered in the surveys had reached very different stages in their partnership careers by the time of data collection, the life table method underlying the calculation of survivorship functions renders the cumulative proportions of ever-partnered women and men comparable and permits us to draw conclusions before the process of union formation is complete.

Starting from Estonia, with the longest cohort span covered by the survey, the data reveal a continuous and extensive shift towards a younger entry into first union, which evidently started in the pre-FFS generations. This long-term shift in the timing of union formation relates to the disappearance of the West European marriage pattern, discussed in the previous sections. In the three oldest cohorts of the Estonian FFS, born in 192438 , the juvenation of partnership formation was mainly concentrated on the later end of the age spectrum: the biggest increase in the cumulative percentage occurred beyond age 25. At the same time it is interesting to note that the referred shift did not pertain to the ultimate proportion of ever-partnered - by age 50, about 95 per cent of women (as well as men) had entered conjugal union, a level that does not vary noticeably across cohorts.

In the following generations, changes in the timing of first union shifted towards the younger end of age spectrum. For example, from the 1939-43 cohort to the 1964-68 cohort the percentage of women who entered their first partnership before age 20 more than doubled. Indeed women born in the youngest cohort 1969-73 started their first partnership very early: nearly one fifth of them were already partnered by the age of 18 . Similarly, among Estonian men the juvenation has been quite intensive, particularly in the birth cohorts of the 1940s and 1950s. Regarding younger cohorts born in the 1960s, however, the juvenation appears to have slowed down among men.

Although a shorter cohort span in the Latvian FFS prevents us from following the developments in the generations born before 1945, the comparison of survivorship functions reveals a noticeable shift towards earlier union formation in Latvia also. 
Figure 1: Timing of entry into first union.

Baltic countries, birth cohorts 1924-73

Estonia: females

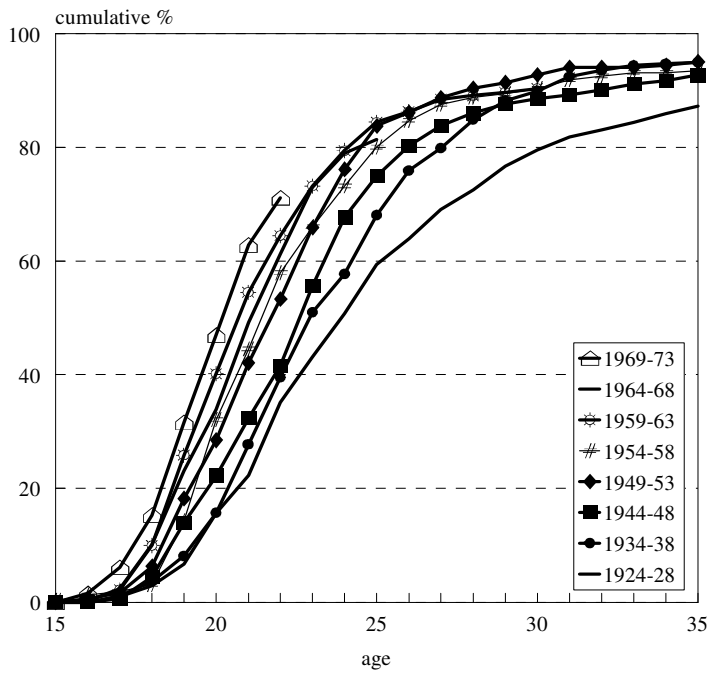

Estonia: males

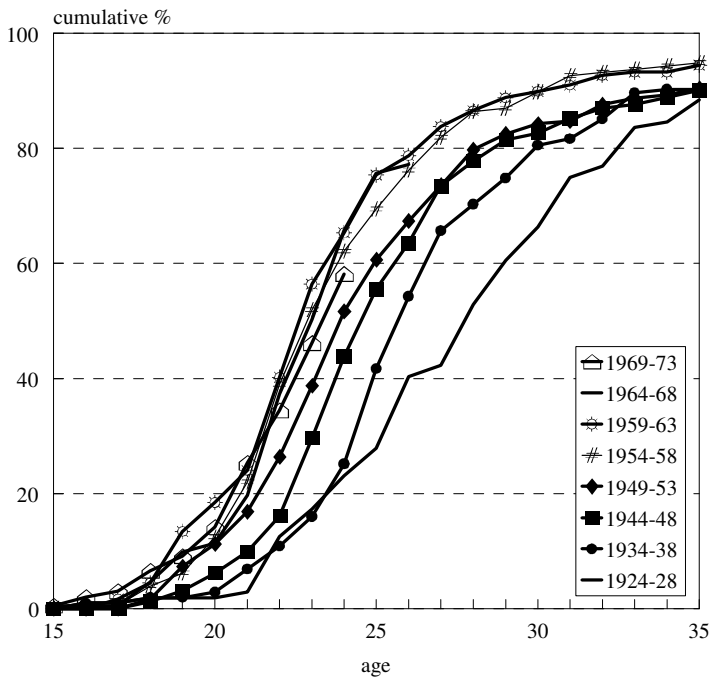


Katus et al.: First union formationin Estonia, Latvia, and Lithuania

Figure 1: (continued)

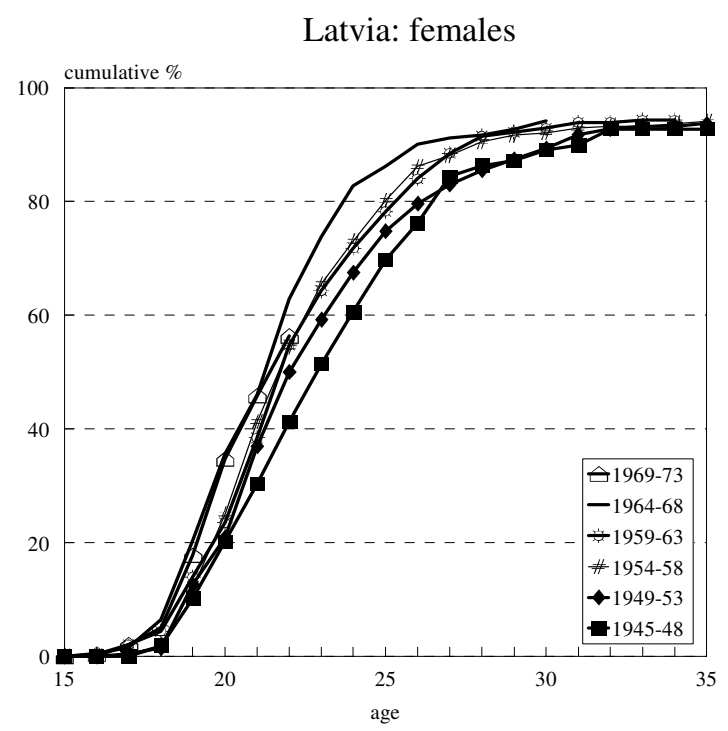

Latvia: males

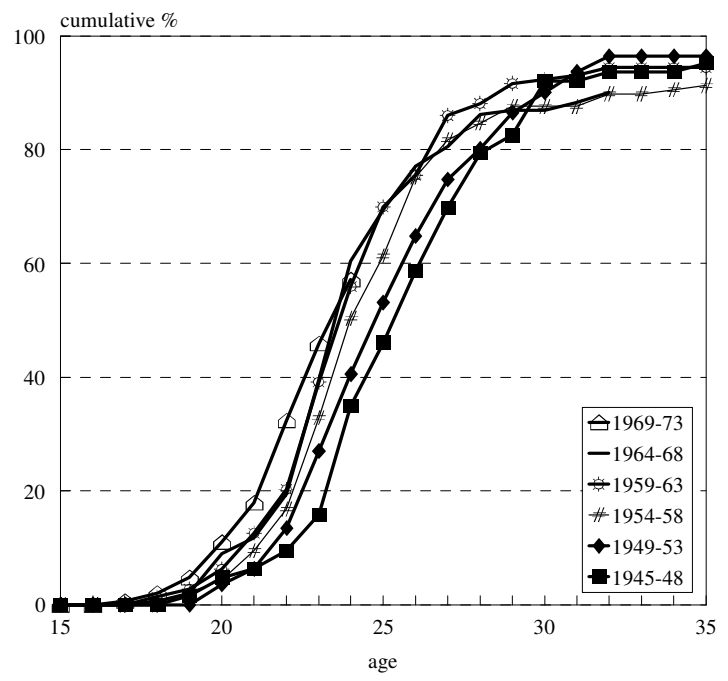


Figure 1: (continued)

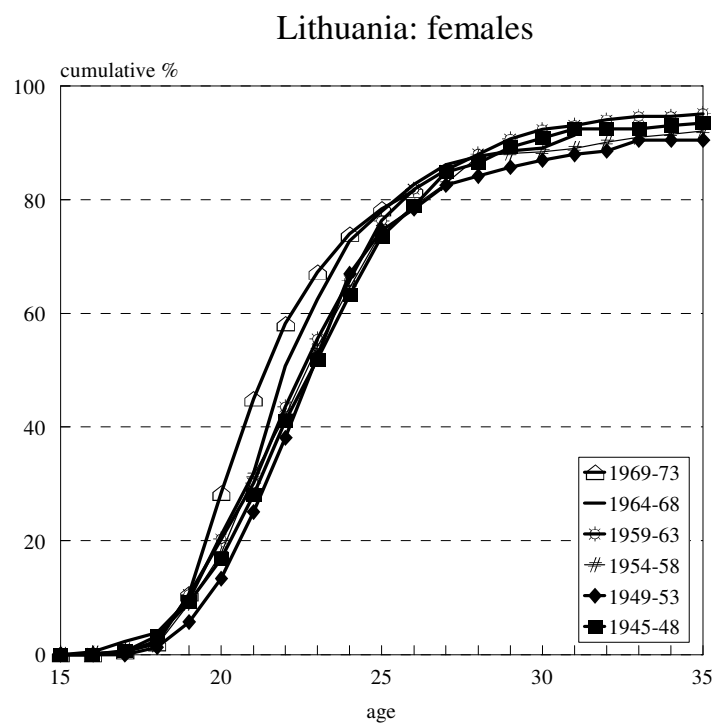

Lithuania: males

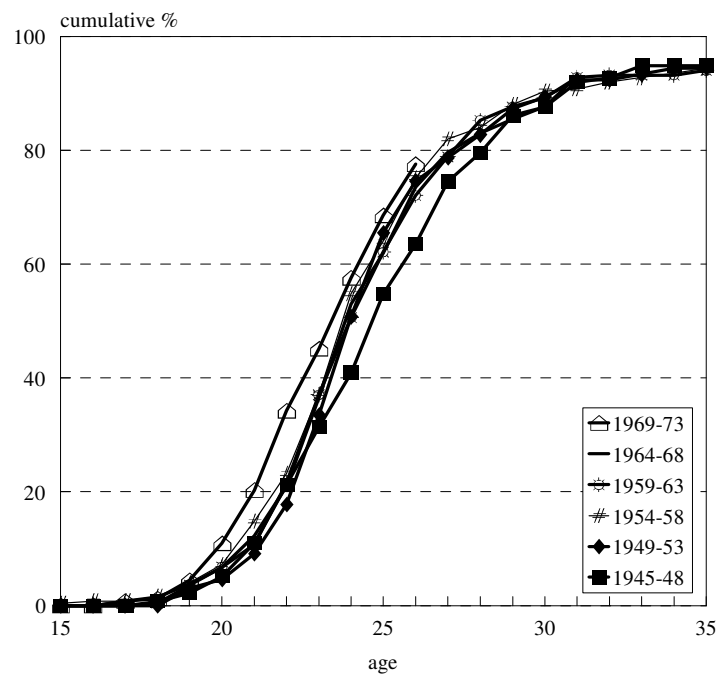

Source: FFS database 
With respect to females, a more or less continuous juvenation can be traced until the 1964-68 birth cohort, which reached the prime age of partnership formation in the late 1980s. Only in the youngest generation does the shift towards earlier union formation display some signs of slowing down. A systematic and relatively extensive shift towards earlier union formation is characteristic of Latvian men as well: the proportion of men who had started their first union by age 21, for example, almost tripled between the 1945-48 and 1969-73 birth cohorts. In general, populations of Estonia and Latvia exhibit largely similar trends in the timing of union formation when judged by survivorship functions.

The shift towards earlier union formation can also be observed in Lithuania, but following a somewhat different trajectory. Unlike its neighbors, there was virtually no change in the timing of entry into first union formation in Lithuania among the female cohorts born between the late 1940s and early 1960s. Leaving aside apparently random fluctuations in older age intervals, in the prime age of partnership formation survivorship functions virtually coincide for these birth cohorts. A clear shift towards earlier union formation becomes evident only in a couple of the youngest five-year cohorts. A basically similar conclusion can be reached for men, although there are slight differences associated with specific cohorts.

Similarities and dissimilarities in the timing of union formation across the three countries can be conveniently summarised by means of median age at entry into first union. First of all, the evidence from Figure 2 is generally consistent with the findings based on marriage registration and confirms the prevailing tendency towards earlier union formation in the Baltic region in the 1970s and 1980s. With respect to both women and men it is also interesting to note a high degree of similarity in the median age of union formation between the countries among the birth cohorts of the 1940s (the earliest cohorts for which the FFS data are available for all three countries). Judging by the evidence drawn from marriage registration - a more or less parallel decline in the mean age of first marriage after the disappearance of the West European marriage pattern - the observed similarity can probably be extended to the preceding birth cohorts covered in the Estonian survey. 
Figure 2: Median age at entry into first union.

\section{Baltic countries, birth cohorts 1924-68}

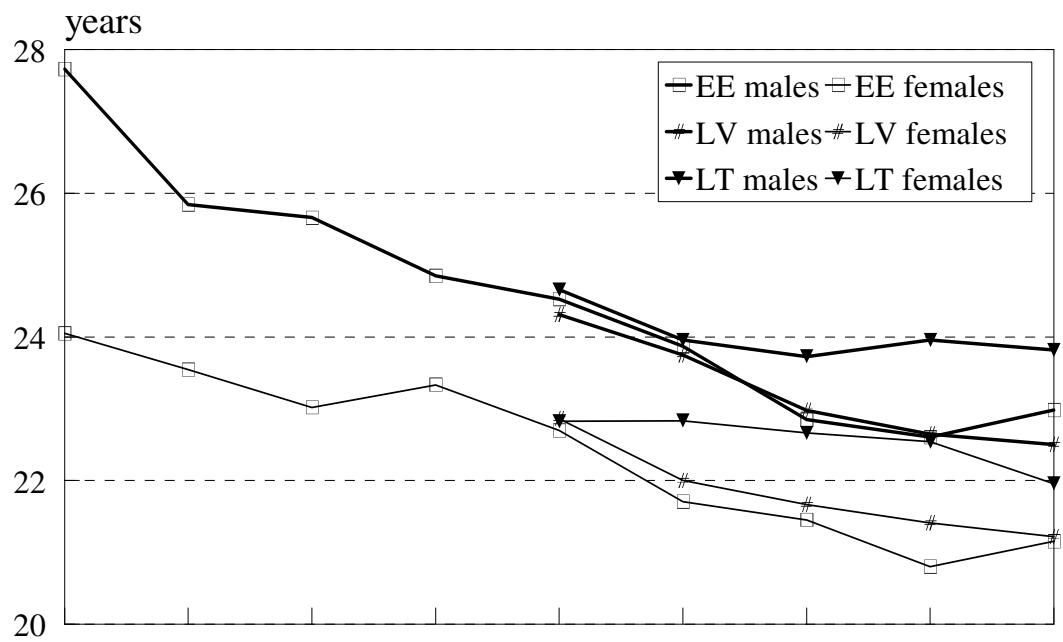

1924-28 $1929-33 \quad 1934-38 \quad 1939-43 \quad 1944-48 \quad 1949-53 \quad 1954-58 \quad 1959-63 \quad 1964-68$

birth cohort

Source: FFS database

Although the trend towards earlier union formation has been predominant in all three countries, the figure also points to country-specific peculiarities that appear starting from the birth cohorts of the early 1950s. In Estonia and Latvia, the median age at first union continued to decline, and a further shift towards earlier union formation followed until the generations born in late 1960s in Latvia and in mid-1960s in Estonia (the very youngest FFS cohorts are excluded because of censoring). Consistent with the observation from survivorship functions, in the same generations in Lithuania the juvenation of partnership formation came to a halt and the median age at first union remained largely unchanged. This resulted in a growing difference in the timing of union formation that peaked in the 1959-63 birth cohort. In that generation, Estonian women started their first partnership on average 1.7 years earlier than their Lithuanian counterparts, for men the corresponding difference was somewhat smaller, accounting for 1.2 years. In general, this difference may not seem particularly substantial but it should be considered against the background of similarity in the earlier generations. And as a result of the stronger continuity of the trend, the scope of overall juvenation in union formation appears to have been more pronounced in Latvia and Estonia. 
The data from other FFS countries offer a favourable opportunity to place union formation in the the Baltic region into a wider comparative perspective. Figure 3 presents the median age at first union for women in the cohorts born in the early 1960s, who shaped partnership formation observed before the turn of the 1990s. In general, the data highlight a considerable diversity in the timing of partnership formation, although the contrast between the earliest and latest entry into the first union appears less extensive than suggested by marriage registration (according to the database of the European Population Committee, the range of variation in the mean age of first marriage accounted for six years in the corresponding period).

Figure 3: Median age at entry into first union. Baltic countries in comparative perspective, female birth cohorts 1959-63

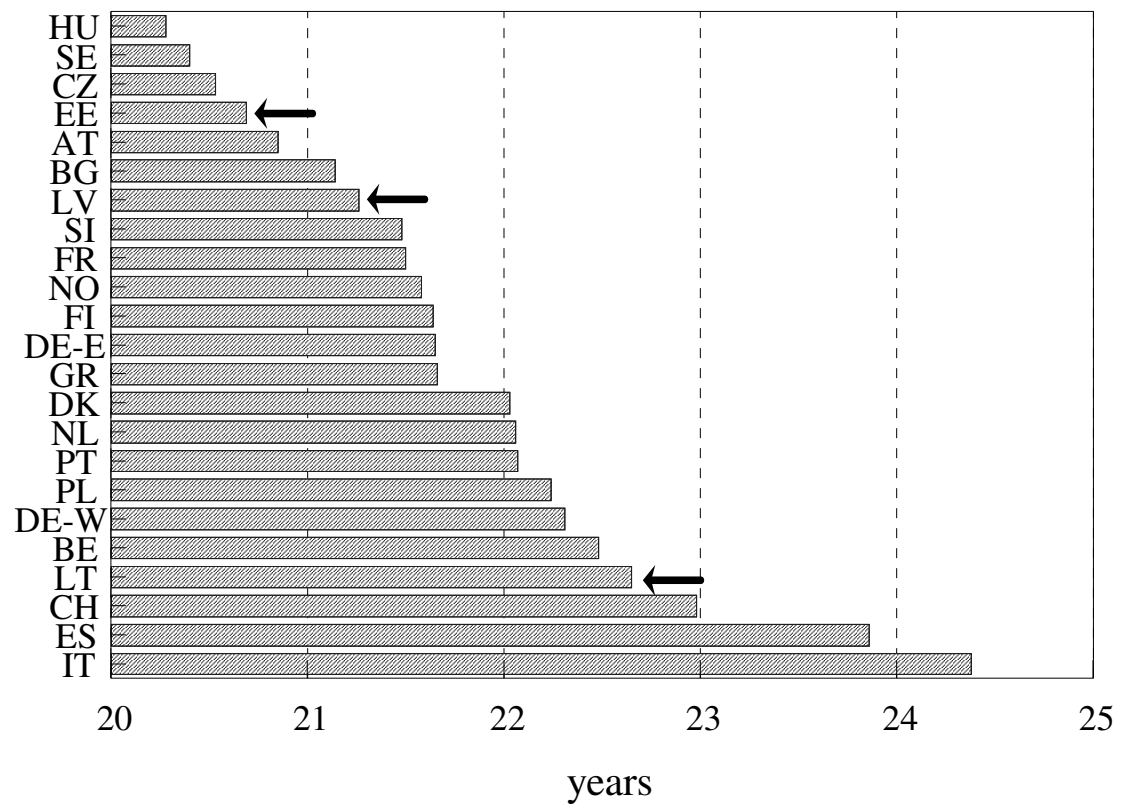

Source: FFS standard country reports

The comparison indicates that Estonia and Latvia belonged to the countries with relatively early entry into first union, which once again underlines the extent of the shift towards earlier partnership formation. The three FFS countries with the lowest median age at first union include Hungary and the Czech Republic, which is consistent with the expectations derived from marriage statistics, however, perhaps more unexpectedly the 
top three also includes Sweden that has for several decades held the position of the latest-marrying nation in Europe. Likewise, a fairly early partnership formation median age around 21.5 years for females - is characteristic of other north European countries for which the comparable data are available. This seeming inconsistency with marriage statistics is of course not spurious but reflects the disconnection of de facto union formation from marriage, which is most strongly pronounced in the latter region.

Turning back to the Baltic countries, the comparison with other countries also exemplifies the distinct pattern of union formation in Lithuania. According to figure 3, among the FFS countries Lithuania features the fourth highest age at first partnership formation after Italy, Spain and Switzerland. It is important to note that the relatively late onset of union formation in Lithuania is not restricted to women born in 1959-63, but is almost equally characteristic of most other cohorts covered by the survey.

\subsubsection{Mode of union formation}

A characteristic feature of modern family initiation has been the disconnection of partnership formation from marriage. As noted above, over the past three decades it has become increasingly common for young people in many countries to start living together without being married. With respect to the Baltic region, the FFS offers the first possibility to explore the diffusion of this behavior on the basis of nationally representative data.

In the life course framework, the prevalence of cohabitation usually refers to the mode of union formation, making the distinction between direct marriage and cohabitation, which may or may not be converted into marriage at a later stage. Marriage represents a traditional pathway of partnership formation whereas the other modes reflect the growing acceptance of partner relations outside marriage, either as a prelude to marriage at the beginning of the union or as a more permanent living arrangement. Figure 4 presents the corresponding percentages in Estonia, Latvia and Lithuania against the total number of women and men who have started their partnerships in a given cohort, filtering out the individuals who remained single by the time of the survey.

Even a brief glance at the figure is enough to reveal an extensive inter-cohort change in the mode of union formation as well as a difference between the countries. Perhaps the most striking feature is that in Estonia, direct marriage had already lost its overwhelming predominance by the earliest generations covered by the survey - direct marriage accounted for about two thirds of first unions, a proportion that remained fairly stable in the 1924-38 cohorts. Starting with the cohorts born in the 1940s, who formed their first partnerships mainly in the 1960s and early 1970s, the proportion began to 
decrease rapidly. In the 1944-53 birth cohorts it dropped below 50 per cent, which means that for the first time consensual union had replaced direct marriage as the mainstream route to family building. In the following generations entry into partnership through direct marriage gradually became an exception rather than a rule: in the 196973 cohort 11.2 per cent of men and only 5.9 per cent of women started their first conjugal union without preceding cohabitation. ${ }^{14}$

Figure 4: Mode of union formation.

Baltic countries, birth cohorts 1924-73

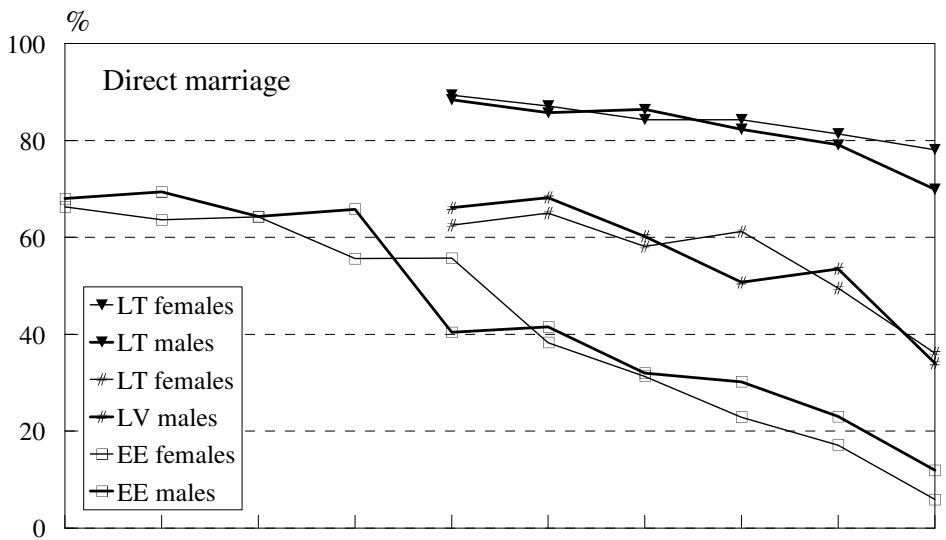

1924-28 $1929-33 \quad 1934-38 \quad 1939-43 \quad 1944-48 \quad 1949-53 \quad 1954-58 \quad 1959-63 \quad 1964-68 \quad 1969-73$

birth cohort

${ }^{14}$ For the youngest cohorts the decrease is slightly overestimated because it does not consider unions contracted at older ages. A systematically higher proportion of direct marriage among men born in the $1960 \mathrm{~s}$ and 1970 s, compared to women in the same cohorts, evidently reflects the later date of data collection in the male survey of the Estonian FFS. 
Figure 4: (continued)

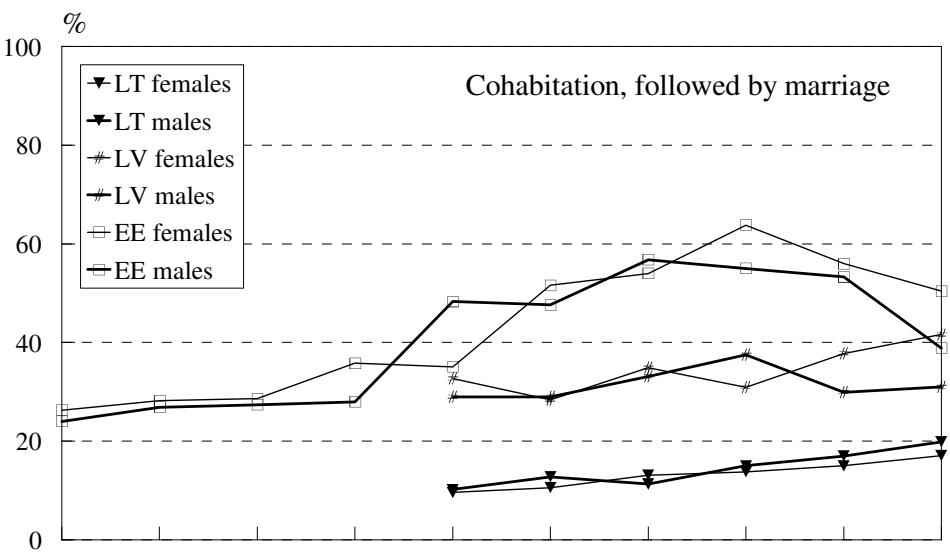

1924-28 $1929-33 \quad 1934-38 \quad 1939-44 \quad 1944-48 \quad 1949-53 \quad 1954-58 \quad 1959-63 \quad 1964-68 \quad 1969-73$

birth cohort

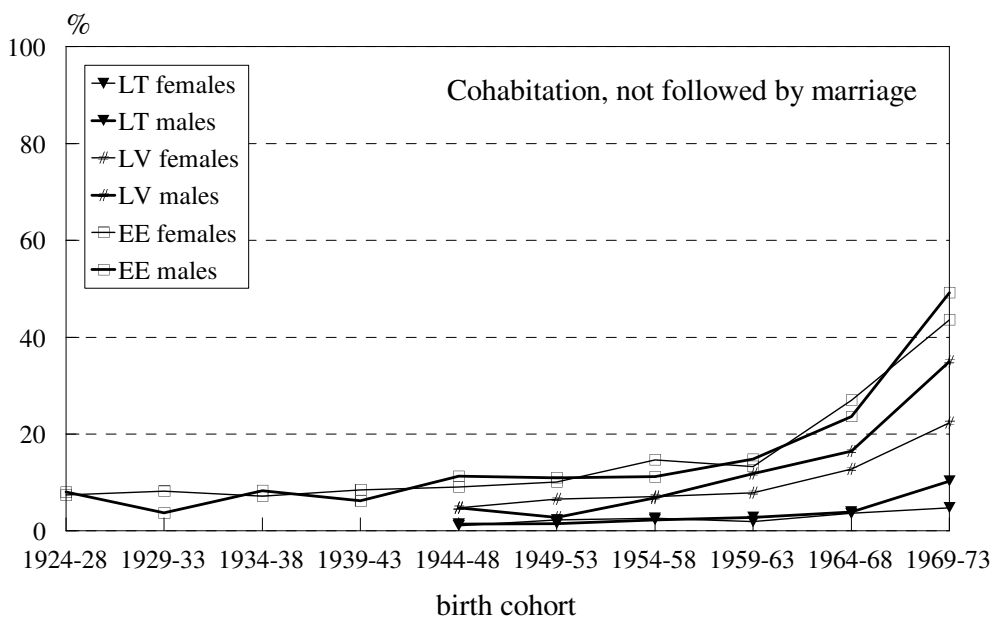

Source: FFS database

Latvia seems to have followed the same trajectory, but judging by the proportions of direct marriage and cohabitation, it lagged behind Estonia for approximately 15-20 years. The change in the mode of union formation progressed somewhat more slowly and the proportion of direct marriage fell below 50 per cent in the cohorts born in the late 1960s. In Lithuania, the adherence to the traditional mode of union formation has 
clearly been more persistent with direct marriage accounting for 90 per cent of first partnerships in the earliest generation. Although there has been a downward trend across the FFS generations, in the cohorts born in the early 1970s around 70-80 per cent of Lithuanian men and women still started their first partnership as direct marriage. The difference in the patterns is also emphasized by the fact that in the youngest Lithuanian cohorts the proportion of direct marriage exceeds the corresponding levels observed among the oldest FFS cohorts in Latvia and Estonia.

The second and third panels of Figure 4 indicate that the decrease in the proportion of direct marriage has resulted mainly from the increase in cohabiting unions which were followed by marriage. In Estonia, the proportion of unions that started as cohabitation but were converted into marriage at a later stage ranged between 25-30 per cent in the oldest FFS cohorts. In the 1939-58 birth cohorts this proportion more than doubled but after reaching a peak the trend reversed. This reversal in the trend indicates a change in the nature of consensual unions - starting from the cohorts born in the early 1960s the data reveal a sharp increase in the proportion of consensual unions which had not been transformed into marriage. Although the latter development could be attributed partly to the censoring of observation at the time of the survey, the break in behavioral patterns is beyond doubt. From the viewpoint of partnership career, this implies a rapid extension in the duration of unmarried cohabitation, which tended to be relatively short until the youngest FFS cohorts. In Estonia, about one half of the partnerships that started as cohabitation were converted into marriage by the end of the first year, by the end of the second year the corresponding proportion accounted for 65 70 per cent (Katus, Puur and Põldma 2002).

In Latvia, and particularly in Lithuania, the prevalence of consensual union has been lower. Despite acceleration of the changes towards the end of the cohort range, neither Latvia nor Lithuania had yet experienced a decrease in the proportion of consensual unions converted into marriage. In a broader framework it seems plausible that the variation in the mode of union formation also accounts for the differentials in the timing of union formation observed between countries. Less binding legal and social obligations associated with consensual unions, together with higher and more rapidly increasing prevalence of non-marital cohabitation, could at least partly explain the lower average age at partnership formation in Estonia and Latvia, discussed in the previous section. This assertion is supported by the relatively close similarity between the Baltic countries with respect to median age at first marriage: the range of inter-country variation in the latter was, on average, limited to 0.4 years among women in the FFS cohort range.

Figure 5 places the mode of union formation in Estonia, Latvia and Lithuania into comparative perspective with the other FFS countries. The data presented for comparison represent the cumulative percentage of women born around the second half 
of the 1960s who had started their first partnerships by age 25, either through direct marriage or cohabitation. In this figure the countries are ranked according to the proportion of consensual unions among all partnerships, the remaining proportions, taking the totals to 100 per cent, account for women who remained single until their 25th birthday. In all countries but a few - such as Italy, Spain and West Germany around 70-80 per cent had entered a conjugal union by the time of the survey, which confirms the comparability of the results.

In general, the data reveal significant differences across, as well within, the regions in Europe. As well known, the vanguard consists of the countries of northern Europe, headed by Sweden and Denmark, commonly regarded as the trendsetters of new family patterns. At the other extreme, non-marital cohabitation still appears to be relatively uncommon in southern Europe, exemplified by Italy and Spain. Against that background, the Baltic countries are dispersed all over the spectrum of union formation behaviour. Among the FFS countries included in the comparison, Estonia holds the fourth position from the top, after Sweden, Denmark and Finland. Lithuania, on the other hand, can be found among the four countries in the bottom group, before Spain, Italy and Poland. In other words, the patterns in Lithuania and Estonia really refer to the takeoff and concluding stage in the spread of non-marital cohabitation.

\section{Figure 5: Mode of union formation. Baltic countries in comparative perspective, female birth cohorts 1964-68}

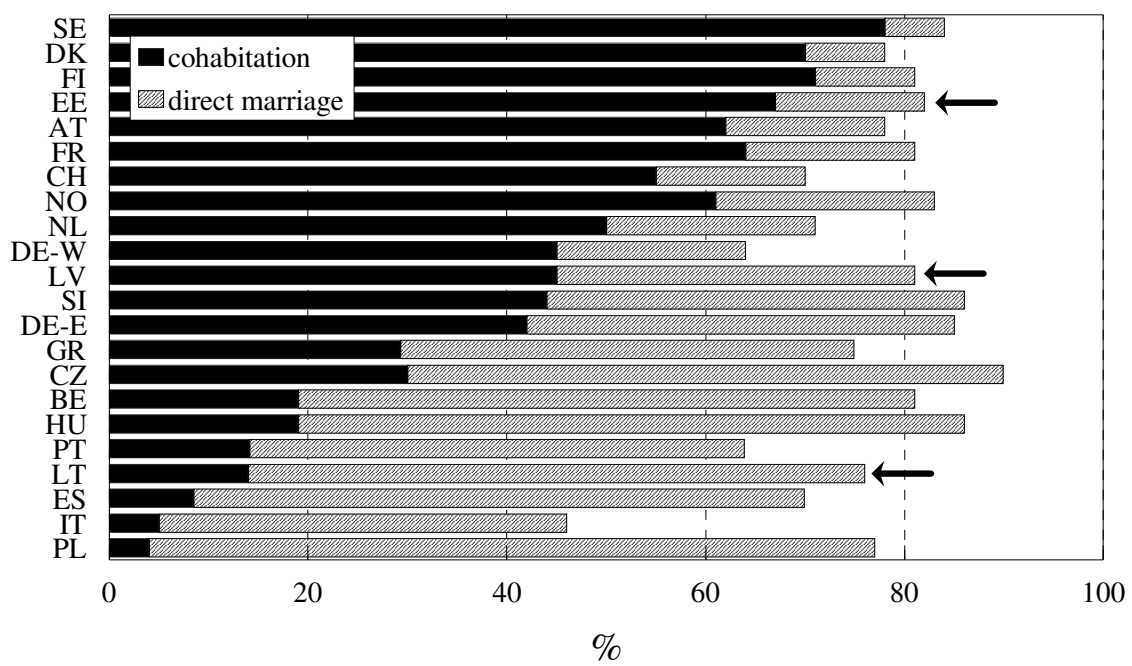

Source: FFS standard country reports 
Between these two extremes, Latvia belongs to the middle group of countries, occupying the position next to West Germany. It is also worth noting that in Latvia starting a partnership as unmarried cohabitation appears to be more common than in Slovenia and East Germany, the two other eastern bloc countries which feature a relatively high prevalence of consensual unions.

In a broader framework of demographic trends, the prominent role of consensual unions in Estonia and Latvia can also be seen in the levels of non-marital childbearing. Following the post-war turbulence caused by Sovietisation, the proportion of nonmarital births has increased steadily in both countries since the late 1960s, independent of overall fertility. By the end of the 1980s it had almost doubled and reached 25 per cent in Estonia, while in Latvia close to 18 per cent of all children were born out of wedlock. Considering the native population, the corresponding figures were noticeably higher, lagging behind only Denmark, Iceland, Sweden and Norway (Katus 1997; 2003). The evidence from the FFS attributes this growth almost entirely to the spread of cohabitation - in both Estonia and Latvia the proportion of births to single mothers, neither married nor cohabiting with a partner, fluctuated at levels between 6 and 10 per cent. At the same time, Lithuania experienced virtually no increase in non-marital childbearing and by the end of the 1980s the proportion of non-marital births accounted for about 7 per cent of all children born in the country, basically the same proportion as three decades earlier.

\subsection{Modelling the gender difference in union formation}

In the following sections, gender differences in union formation are examined in the micro-level framework, with the main interest in the effects of educational attainment and labour force participation. To model the transition from single status to first union a series of hazard rate models were estimated. In this particular case, Cox's semiparametric model is used, which can be expressed as

$$
\mathrm{r}(\mathrm{t})=\mathrm{h}(\mathrm{t}) * \exp (\mathrm{bX})
$$

where $\mathrm{r}(\mathrm{t})$ is the hazard rate at which the event under consideration occurs at time $\mathrm{t}, \mathrm{h}(\mathrm{t})$ is the so-called baseline rate at $\mathrm{t}$, and $\mathrm{X}$ is a vector of covariates, upon which the occurrence of the event is assumed to depend.

The main advantage of the Cox model is that the time dependence of the process does not have to be modelled. In the model, the baseline hazard can be left unspecified and the parameters are estimated applying a partial likelihood method. This is convenient in the multivariate framework, if one is not primarily interested in the shape 
of time dependence but in the associations between the hazard rate and covariates, controlling for time dependence of the event. As with other event history models, it integrates survival times and censored observations, and can also easily accommodate time-dependent covariates to study interdependent processes, which form an essential component of this analysis. A potential limitation of the Cox model is that, if the effects of covariates vary with duration, the parameter estimates will be biased. ${ }^{15}$. Although the requirement of proportionality restricts the range of potential applications, the Cox model has been widely used in empirical analysis, including family formation and dissolution (e.g. Blossfeld 1995; Liefbroer and Corijn 1999; Mills 2000; Rao 1990).

\subsubsection{Variables, hypotheses and operationalisation}

The dependent variable in our models is the rate of entry into a first conjugal union. The exposure is measured in months, starting at the age of 14 of the respondent and continued until the entry into first union, whether by marriage or cohabitation, or until censoring at the interview, whichever event comes first. In view of extensive differences in the mode of first partnership formation across countries and cohorts, discussed in the previous section, separate modeling of entry into union through marriage and cohabitation was not attempted in comparative setting.

Proceeding from the theoretical considerations outlined in the introductory section, the independent variables of main interest in this study relate to education and labour force participation. With respect to education, previous research has underlined the importance of making a distinction between educational enrolment and attainment.

The incompatibility between educational enrolment and union formation seems to be a common finding across a wide range of national and comparative studies (e.g. Billari and Philipov 2003; Blossfeld 1995; Blossfeld et al 2005; Cherlin 1992; Corijn and Klijzing 2001; Hoem 1986; Liefbroer 1991; Manting 1994). The incompatibility is usually explained by the conflict of interests between spending one's time, energy and money on school or on the family, and more limited resources of students, particularly in comparison with young people who have graduated from school. In the light of the job search theory, Oppenheimer (1988) related the delay in family formation to uncertainty: during a period of educational enrolment uncertainty is large because it is unclear how the individual's human capital and skills can match the demands of the labour market. In the state socialist setting analysed in the present paper, however, this

\footnotetext{
${ }^{15}$ To counter this problem, various tests of proportionality assumption are recommended as a diagnostic solution (Blossfeld and Rohwer 2002). In the stage of exploratory analysis, different model specifications, including piecewise constant proportional hazard models were applied. The results were closely similar to those obtained with the Cox model, indicating the robustness of the findings.
} 
point is probably less relevant. Other explanations that do not necessarily contradict the former have pointed to the societal norms about the sequencing of life course events, in particular the expectation that young people still enrolled in education should postpone family formation until the completion of studies (Blossfeld and Huinink 1991; Waite and Spitze 1981).

The analyses that have covered both women and men have also revealed that the negative impact of educational enrolment on union formation tends to have a somewhat stronger effect on women (Goldscheider and Waite 1986; Corijn and Klijzing 2001). In terms of the gender system, the stronger effect observed among women may reflect role specialisation within the family, according to which women are considered more responsible for the household that they form and the family they create - consequently, the larger share of household and child care tasks assigned to women makes it more difficult for women to combine schooling and family formation. But at the same time, the expectation towards men as main breadwinners puts certain limits to such a genderspecific effect.

Educational attainment represents the highest level of education achieved rather than the individual's educational participation at the time of a life event. According to New Home Economics, women who have attained higher educational levels are economically more independent from men (Becker 1991). Within the micro-economic framework the impact of educational attainment is considered to operate mainly through the accumulation of human capital. With their enhanced earning capacity, more highly educated women have fewer economic gains from partnership and are more likely to postpone or even forego union formation compared to their less educated counterparts. In addition, the opportunity costs of time spent on family increase with human capital and in the context of a gender-specific division of labour within the family, these costs are typically higher among women. As regards men, the income effect has been hypothesised to dominate the relationship in the context of a gendered division of labour. As main providers of the family income, men with a higher earning potential are better equipped to support a family and are therefore more attractive as potential partners, resulting in a positive effect of educational attainment on the timing of union formation.

In the micro-economic framework, the effect of labour force participation has been theorised along similar lines. Men's family responsibilities have been centred around being good providers, thereby reinforcing their labour market role. Full-time employment and an established position in the labour force is therefore usually regarded as a precondition for successful family life for men. Regarding women, one would expect that working women form partnerships at a lower rate, as their respective gains appear smaller and opportunity costs higher compared to non-working counterparts. 
As noted in the introductory section, these views have been contested by arguments suggesting that women's economic independence related to higher educational attainment and labour force participation can actually increase rather than reduce the benefits for a family unit and for its individual members (Oppenheimer 1994; Mason and Jensen 1995). In that case, economic independence might enhance the chances of partnership formation for women. It could do so because it makes women more attractive as partners because they will contribute to household income and will not be dependent on their husbands, or because, just as it probably does for men, economic independence signals some sort of progression to adult status. According to the authors emphasising ideational shift, educational attainment may also operate through value orientations and the weight attached to independence and individual autonomy (Lesthaeghe and Moors 1996; Lesthaeghe 2002).

The empirical research focusing on the impact of educational attainment and labour force participation on union formation has highlighted the salient role of gender and family systems prevailing in different countries (e.g. Blossfeld 1995; Blossfeld et al 2005; Corijn and Klijzing 2001; Ono 2003). In particular, it has been suggested that the impact of education and labour force participation will be stronger, and the gender specifity more pronounced in the countries with more 'conventional' or 'traditional' gender and family systems. Liefbroer and Corijn (1999) pointed out that the direction and strength of the impact of educational attainment and employment depends on the degree of (in)compatibility of labour market participation and family formation in the societies under consideration, which can be discerned at a cultural and structural level. The former relates to values, norms and ideologies concerning the roles of women and men in society and in the family, the latter to the existing opportunities and constraints on these roles. The results of comparative studies suggest that the more advanced is the society in terms of gender equality, the less polarised the effect of educational attainment and labour market participation between women and men will be.

These considerations along with the features of comparative setting lead us to formulate the hypotheses that will be tested by means of event-history models. Consistent with the finding prevailing in previous studies, we expect to find a negative effect of educational enrolment with limited variation across gender and countries. For men we hypothesise that employment will enhance the probability of union formation but the expectation concerning educational attainment is less obvious. As elsewhere in the centrally planned economies returns to education were low in the Baltic countries and the administrative wage setting mechanisms favoured manual occupations. Therefore we do not predict a positive effect of advanced education among men in any of the three countries.

Since economic independence may simultaneously promote women's union formation, and impede it, we are uncertain about the net effects of educational 
attainment and employment on union formation among women. On the one hand, all three countries feature an established dual-earner family model, high level of female labour force participation, supportive coverage of public childcare, and parity with men in terms of schooling. Under these conditions, women's employment and education should have no negative effect on the rate of union formation, in the same vein as it has been observed, for example, in Scandinavia and the countries of Eastern Europe [e.g. Blom 1994; Bracher and Santow 1998; Olah and Fratzcak 2003]. On the other hand, however, little is known of to what extent the state-decreed emancipation influenced gender relations and attitudes in the private sphere. For these reasons, we have to remain agnostic about the direction of the net effect among women and the similarity of patterns across countries.

As regards the operationalisation of variables, educational enrolment and labour force participation are introduced in the models by means of a combined time-varying covariate with three levels, which refers to the main activity status of the respondent: enrolled in education, employed and non-employed. A further distinction between fulland part-time employment was not attempted because of very low prevalence of parttime employment in the Baltic countries. For a similar pragmatic consideration, a more refined classification of the non-employed was not attempted as it would have resulted in very small numbers. In the late state socialist setting, unemployment was virtually non-existent and a shortage of labour prevailed. Moreover, to be out of the labour force, a person required an officially acceptable excuse such as study, illness or poor health, conscription into the army, a very young child etc.

Educational attainment refers to the highest level of education the respondents have successfully completed. Apart from school enrolment, educational attainment has been operationalised as a time-fixed covariate. The indicator of educational attainment distinguishes between three levels: low (less than upper secondary), medium (upper secondary) and high (tertiary) educational attainment. An alternative option was the construction of a time-varying covariate. This might have been preferable for capturing the person's current earnings capacity. However, educational attainment also relates to intellectual competence and certain preferences, which cannot be expected to change from one month to the next when the diploma/degree is received (Liefbroer 1991). In the late state socialist setting, where returns from education in terms of wages were administratively smoothed, non-economic aspects of education were perhaps even more important than in market economies.

The control variables included a set of socio-economic and demographic characteristics, which are known from previous research to differentiate the tempo of union formation. These characteristics include birth cohort, past life course experiences (growing up in a single parent family, number of siblings, type of settlement in childhood, departure from the parental home) and current life course experiences 
besides education and labour force participation (having a pre-union pregnancy/birth). Among these variables, departure from the parental home and having a pre-union pregnancy/birth were operationalised as time-varying covariates, while the rest of the controls represent fixed variables.

The models also include religiosity which has historically made a noticeable distinction among the Baltic countries. Studies from many countries (Corijn and Klijzing 2001; Manting 1994; Nazio and Blossfeld 2003; Rao 1990) have pointed to the importance of religious affiliation for family behaviour, and although the effect of religion on the timing of union formation appears less evident, it was considered essential to incorporate this dimension in the analysis ${ }^{16}$. In terms of operationalisation religiosity refers to self-definition, persons who described themselves as religious are so defined. Given the aims of the study, it would also have been worthwhile to include some attitudinal characteristics relevant to the division of gender roles but the data did not support comparable information for all the countries.

Appendix Table 1A provides information on the number of observations and the distribution of covariates (exposure time) included in the models in each country, separately for men and women.

\footnotetext{
${ }^{16}$ Earlier analyses based on the FFS data have also revealed the effects of religion in Estonia, particularly with respect to the type of first union (Katus, Puur, Põldma 2002).
} 


\subsubsection{Modelling results}

The modelling strategy applied in the study is straightforward. Women and men were analysed separately for each country in order to detect possible differences in the effects of individuals' characteristics on the rate of first union formation by gender and country $^{17}$. For each unit of analysis, four sets of models were fitted. The purpose of the first set was to produce non-adjusted estimates for each of the covariates by including them one at a time in addition to age (duration). In the second step, the model included only individual characteristics such as cohort, family of origin, the number of siblings, settlement type and religiosity. Next we included the rest of control variables, and in the final step, the covariates of main interest in this paper (educational attainment and activity status) were added. Such stepwise inclusion of covariates reflects the sequence in which they appear in the life course of the respondents, which in turn determines their causal proximity to the life situation of the respondent as observed in the survey.

The model fitting was done using the SPSS software package. The results, produced as partial likelihood estimates of the effect parameters in the model, are presented in the form of relative risks. Estimates from the final sets of models, together with the applied coding schemes of covariates, the choice of reference categories and statistical significance levels, are presented in the tables that follow. Table 1 summarises the results for the variables of main interest.

Consistent with the expectations and findings commonly observed in other settings, enrolment in education has a negative effect on the start of the family formation process. Being currently at school indeed appears to be incompatible with the role of a conjugal partner and clearly postpones the entry into first union. The direction of the gradient is the same and the effects are statistically significant. With the exception of men in Estonia, the risk of union formation is almost halved in all three countries. The comparison of adjusted and non-adjusted estimates reveals that the influence of educational enrolment is relatively independent - the control for past and current experiences life course other brings about only minor change in relative risks.

\footnotetext{
${ }^{17}$ Multivariate analysis leaves aside older generations of the Estonian FFS and focuses on the birth cohorts starting from 1944 for all three countries.
} 
Table 1: Relative risks of starting a first union for education and activity status

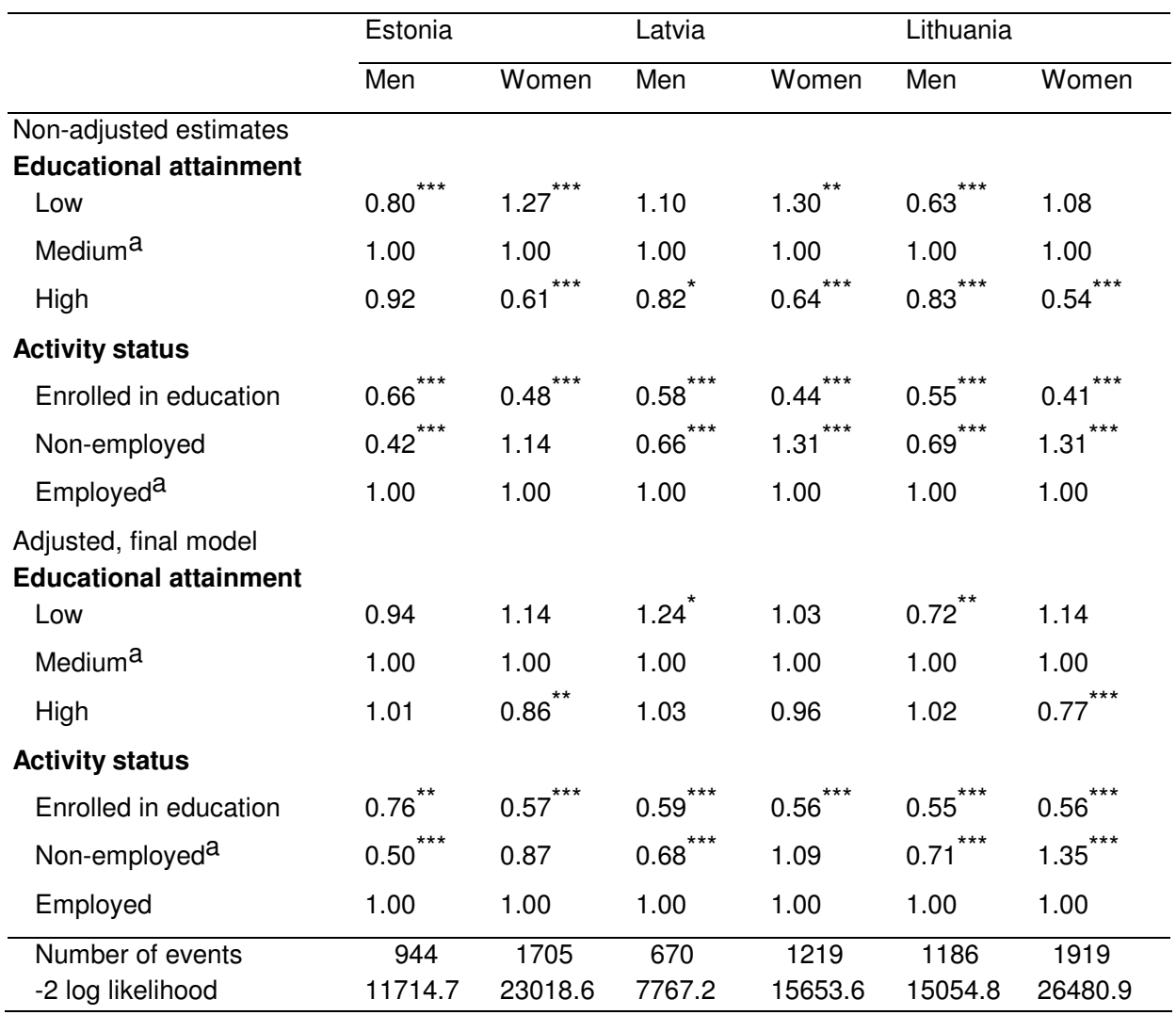

${ }^{* * *} \mathrm{p}<0.01,{ }^{* \star} \mathrm{p}<0.05,{ }^{*} \mathrm{p}<0.1 ;{ }^{\mathrm{a}}$ Reference category

The gender difference in the effects of educational enrolment appears small. In Latvia and Lithuania, the model estimates are basically similar for men and women. Only in the case of Estonia do the relative risks indicate a somewhat lower incompatibility between school enrolment and union formation among men compared to women. The prevailing similarity of the results suggests that the effect of educational enrolment is likely to be driven by constraints that operate in more or less the same way in all three countries with no significant discrimination between men and women.

Compared to school enrolment, the results for educational attainment are generally less pronounced but at the same time they reveal greater diversity across gender as well 
as countries. Starting from the bottom of educational hierarchy, in all countries women with less than secondary education feature a slightly higher propensity for union formation compared to the reference group, respondents who have completed upper secondary education. Once school enrolment is taken into consideration, the relative risk ranges between 3 per cent in Latvia and 14 per cent in Lithuania (Estonia stands very close to the latter level). Due to the relatively small number of respondents in the cohorts born after the Second World War, in none of the countries does the corresponding difference reach the level of statistical significance ${ }^{18}$.

Among men with low educational attainment, the effect tends to go in the opposite direction, to a minor extent in Estonia and noticeably in Lithuania. The level of education below upper secondary is associated with a reduced probability of starting a partnership, in Lithuania the corresponding relative risk is nearly 30 per cent lower compared to the reference group, a difference that is statistically significant. From the viewpoint of partnership formation, low educational attainment evidently translates into reduced attractiveness and constitutes a disadvantage for males in the Lithuanian marriage market. Against that background, Latvian men seem to be outliers with an elevated risk of union formation among the group of the less educated.

With respect to higher educational attainment, the varying negative effect observed in non-adjusted estimates disappeared among men in all three countries once the duration of education (enrolment) is controlled for. To this end it is interesting to note that estimates for relative risks were very similar and none of the countries developed a positive gradient. This implies that among men, net of other factors, higher educational attainment is neutral with respect to union formation in the Baltics. Unlike men, a negative effect of higher education still prevailed among women. At the same time, however, the impact of advanced educational attainment was dissimilar across countries. In Estonia, and particularly in Latvia, completion of tertiary education was associated with a relatively moderate reduction in the rate of partnership formation whereas in Lithuania the effect appears to be more pronounced (relative risk nearly 25 per cent lower compared to the reference group).

Regarding labour force participation, the effect of non-employment for reasons other than school enrolment can be analysed. Table 2 reveals that among men, being out of employment features a consistently negative association with the propensity for partnership formation across the countries. In Latvia and Lithuania non-employment implies around 30 per cent reduction in the rate of entry into first union. In the case of Estonian men, the reduction of relative risk is even greater but the corresponding difference with their Latvian and Lithuanian counterparts may well represent a statistical artifact resulting from data collection rather than a true behavioural distinction. Non-

\footnotetext{
${ }^{18}$ It is interesting to note that while the control for school enrolment leads to significant reduction of relative risks for low-educated women in Estonia and Latvia, the opposite appears true for Lithuania.
} 
employment for reasons other than school enrolment was relatively infrequent in the state socialist setting, and for young men the most common reason was military service. The experience from the FFS data collection exercise revealed that unless the interviewers were given careful instruction, military service could easily be underreported. Compared to other statuses coded as non-employment in the survey, conscription in the armed forces is highly incompatible with the start of conjugal union and even moderate underreporting may influence the estimated model parameters. In the Estonian FFS, special attention was paid to the recording of compulsory military service as a separate episode in men's activity biography. Compared to Latvia and Lithuania, this may have resulted in a more complete reporting of military service in the Estonian survey, and consequently, in a stronger effect of the corresponding covariate. Such a possibility is suggested by the distribution of exposure time in Appendix Table 1A but unfortunately is not possible to test this hypothesis directly as the FFS standard recode file does not have a separate code for compulsory military service.

Among women, the geographical pattern appears noticeably different. In Estonia, after controlling for other factors, non-employment leads to a postponement of union formation, although compared to men the effect is less pronounced and is not statistically signficant. In contrast, in Latvia and particularly in Lithuania female nonemployment seems to speed up union formation. In the case of Lithuania, the propensity for starting a union among non-employed women exceeds that in the reference group by more than a third and reaches the level of statistical significance.

To sum up the findings with respect to education and labour force participation, there were only limited differences in the effects of educational enrolment. In all three countries, school attendance brings about the reduction in the rate of union formation among both women and men. Unlike enrolment, educational attainment displays a variation along both dimensions of interest. In general, a low level of education tends to be associated with a slightly higher rate of union formation among women while for men the opposite effect prevails (with the exception of Latvian men). In contrast, a high level of education among women seems to delay entry into partnership whereas advanced male education is neutral to union formation. Across countries, the polarisation of gender-specific effects of educational attainment appears strongest in Lithuania. The same is true about the effect of female (non)employment that features an interesting transformation in the gradients of relative risk from north to south, achieving the level of statistical significance among Lithuanian women.

Other factors included in the model are beyond the main interest of our analysis and the discussion of corresponding findings is skipped in the paper. Model estimates for control factors are presented in the appendix table. 


\section{Summary and discussion of the findings}

This article addressed patterns of first union formation in the Baltic countries among the generations who started their family life mainly in the 1970s and 1980s, with the aim of placing them in the context of prevailing gender relations.

The analyses of cohort trends revealed noticeable change as well as diversity in the patterns of union formation between Estonia, Latvia and Lithuania. In the FFS cohort range, the timing of a first conjugal union was dominated by a more or less extensive shift towards a younger age at the start of union in all three countries. In a broader view, this juvenation of union formation constitutes part of a long-term trend towards younger and more universal marriage that had started several decades earlier and ended the reign of the West European marriage pattern in the region after WWII.

The change in the timing of unions was paralleled by the transformation in the mode of partnership formation, however, the shift from marriage to cohabitation varied considerably between countries. The results indicate that in Lithuania marriage maintained its position as the prevailing mode of union formation, with only minor modification of the pattern towards younger generations. In contrast, in Estonia, and to a somewhat lesser extent in Latvia, the shift from marriage to cohabitation began well before the fall of the previous regime and onset of societal transition. In the case of Estonia, pre-marital cohabitation was already the prevailing route to family building in the generations born in late 1940s-early 1950s. In Lithuania the differential spread of consensual unions was also reflected in lower prevalence on non-marital childbearing, and in a somewhat later timing of union formation compared to Estonia and Latvia.

As regards Estonia, the dynamics in the cumulative prevalence of cohabitation at entry into first unions resembles that of Sweden, the trendsetter of modern family patterns (Hoem and Rennermalm 1985; Bernhardt and Hoem 1986). What appeared markedly different compared to the latter, however, was the tempo at which unions were converted into marriage. Unlike Scandinavia, cohabitation in the Baltic countries until the 1990s remained a relatively short stage at the beginning of partnership career rather than a long-lasting status. Searching for an explanation for this feature, one can refer to the characteristics of the prevailing societal regime that restrained the ultimate disconnection of partnership formation from marriage and at the same time encouraging relatively early family formation.

In this context, several authors have called attention to the mechanism of housing allocation (e.g. Ni Brolchain 1993; Nazio and Blossfeld 2003; Speder 2005). In the state socialist system, the housing market did not exist and dwellings were distributed according to certain administrative rules. According to these rules, consensual unions were disregarded and to become eligible, a couple was expected to be in a registered marriage, which indeed encouraged young people to register their partnerships. 
Instrumentally, a limited supply of efficient contraceptives, as a result of the prevailing health care policies, had the same effect (Avdeev 1994; David 1999). With respect to Estonia, the plausible impact of housing allocation is indirectly revealed by a more rapid diffusion of non-marital cohabitation in rural areas where the role of the state as a provider of housing was noticeably lower (Katus, Puur, and Sakkeus 2005).

A central analytical focus in this article concerned the differences in union formation, related to education and labour force participation. Variation associated with these characteristics among men and women provides an indication of the compatibility between family life on the one hand, and education and employment on the other. Generally, the positive effects, revealed by multivariate event-history models, point to greater compatibility between the demands of these life domains, competing for the time and energy of individuals, while the negative effects signal difficulties in reconciling them. A comparison of the corresponding patterns between countries sheds light on the characteristic gender systems that facilitate or complicate the reconciliation. Based on the evidence from previous studies of family formation, we expected a greater incompatibility between life domains to be characteristic of more traditional gender systems, compared to more emancipatory systems (Blossfeld 1995; Corijn and Klijzing 2001).

Although the effects of education and labour force participation were not particularly strong, the results indicate noticeable differences, consistent with the hypothesis of contextual contingency referred above. Among the three countries included in the study, the polarisation of the effects of educational attainment and labour force participation between men and women appears the most pronounced in Lithuania. Among men a statistically significant reduction in the rate of union formation was associated with low educational attainment whereas among women, on the contrary, a similar effect relates to high level of education. In the case of Lithuania, the polarised gender-specific effect was found also for labour force participation - being out of employment significantly decreased the risk of starting a union for men, while among women, non-employment was related to higher chances of partnership formation. The direction of the observed effects obviously mirrors the division of gender roles, which regards men as principal income providers and women as carers for household and children.

In Estonia and Latvia, the evidence concerning the polarisation of gender roles, if observed, proved weaker and generally below statistical significance. In comparative perspective, particularly clear cross-country differences were exemplified by female (non)employment. The gradient of the corresponding effect transformed from slightly negative in Estonia, where it followed the same direction among men and women, to slightly positive and having opposite direction compared to men in Latvia, and further to positive and statistically significant in Lithuania. With respect to educational 
attainment, the difference between Estonia and Latvia appears less systematic in revealing a consistent geographic gradient across the entire region.

Why then have these dissimilarities between countries arisen and how do they relate to the functioning of the gender system? With a certain degree of simplification, the arguments used to explain the trends and differentials in the demographic behaviour can be split into two major streams, according to whether they insist on the role of structure or on the role of culture (Billari 2006; Mellens 1999; Pinelli, HoffmannNowotny and Fux 2001). Structural factors relate to the functioning of various societal institutions, policies, instruments of welfare state etc., that shape the opportunities and constraints of individuals. Cultural factors, on the other hand, relate to broad ideologies, values, norms and preferences, which are used to define more and less appropriate ways of living and guide the choice between alternative options.

As mentioned above, structural factors evidently contributed to the rapid conversion of consensual unions into marriage in the Baltic countries before the 1990s compared to Scandinavia, but they can hardly account for the differences within the region during the state socialist regime - at the end of WWII Estonia, Latvia and Lithuania became subjected to far-reaching centralisation, which resulted in very similar profiles with respect to the institutional framework. As shown earlier in the paper, the high degree of uniformity also extended to the societal gender structure, and in that respect all three countries shared a regime that encouraged women's and men's equal access to education and high labour force participation.

As regards cultural factors, it proves difficult to obtain internationally comparable data on values and attitudes related to gender roles on the Baltic populations that would refer to the period until the 1990s. Still, indirect evidence can be drawn from studies which are more recent but cover a large part of the FFS cohorts. A very useful source in this respect is the second round of the Population Policy Acceptance Survey, which was conducted in fifteen European countries in 2000-2003 ${ }^{19}$.

This survey permits the comparison of Estonians and Lithuanians on a wide range of population-related values, beliefs and attitudes, including gender roles. The analyses conducted in the framework of the PPA study have indicated that, on average, Lithuanians tend to hold more conservative views on the family and the division of gender roles. As concluded by Lithuanian researchers, traditional values and norms concerning the roles of men and women in the family are only now beginning to lose their strength in the country (Stankuniene et al 2003). In a comparative perspective, this judgement has been corroborated by the fact that among the fifteen nations covered by

\footnotetext{
${ }^{19}$ Since the beginning of 1990 s, the Baltic countries have also participated in the European Value Surveys program. Compared to PPA, the major drawback of EVS has been its small national samples which make the results less reliable. Among others, this was the reason why Lesthaeghe and Surkyn combined the Baltic countries in their study of values and new family forms in Central and Eastern Europe (2002).
} 
the study, Lithuanians expressed the lowest preference for the currently prevailing dualearner model and strongest support to the male breadwinner model as an ideal for their family. Compared to Estonia, the classical statements 'a pre-school child is likely to suffer when mother works' and 'family life suffers when woman has a full-time job', scored a clearly higher agreement in Lithuania. A comprehensive account of the survey results is available from a forthcoming monograph, edited by Hoehn, Avramov and Kotowska (2008).

Latvia did not participate in the PPA programme but a comparative analysis by Mellens (1999) on the socio-economic and cultural correlates of population development places Latvia rather close to Estonia along the cultural dimension, which, according to the applied conceptualisation, also included gender equity. In the light of the theoretical framework introduced by McDonald (2000; 2002), the differences in gender relations observed between the Baltic countries primarily relate to the family level. As mentioned above, in respect to societal level all three countries feature a similar profile, with a relatively high degree of gender equity in several domains. According to recent EU labour market statistics, for example, the Baltic countries together with Sweden and Finland showed the smallest gender difference in employment rate for the prime working age population (EC 2006).

Additional evidence in support of the varying consistency between gender equity on the societal and the family level can be drawn from the dynamics of fertility trends in the region over the past decade. Following the sharp decline of fertility from close-toreplacement level in the 1980 s, fertility rates fell to very low levels, with TFR reaching 1.2-1.3 in all three countries. After reaching the lowest point, fertility has started to show signs of recuperation all over the Baltic region but the strength of this new development has been noticeably different (Council of Europe 2006). In Estonia, the fertility level has increased by 15-20 per cent compared to its lowest point whereas in Lithuania the increase of fertility appears only marginal. It is also interesting to note that among the new member states of EU from Central and Eastern Europe, Estonia ranks highest in terms of fertility recuperation which can be hardly explained, for instance, with economic arguments. In Latvia, the recuperation is also rather small but it seems likely that the high proportion of foreign-origin population in Latvia may affect the statistics reported for the total population. ${ }^{20}$ But at the same time, the cross-country difference in recent fertility developments basically matches the pattern that, with references to other settings, has been attributed to the inconsistency between gender equity in individual- and family-oriented institutions (Chesnais 1996; McDonald 2000).

\footnotetext{
${ }^{20}$ In Estonia, fertility level among the foreign-origin population have been systematically lower compared to the native population over recent decades (Katus, Puur and Sakkeus 2002). Given the close similarity of demographic development in the two countries, we can assume the same situation to hold also for Latvia.
} 
Turning back to the Baltic region, an essential cultural feature that makes a distinction between Estonia and most of Latvia on the one hand, and Lithuania on the other hand, is religion. As noted earlier, the boundary between the Catholic and Protestant (Lutheran) domains emerged in the region several centuries ago but has survived until modern times. In Estonia and Latvia secularisation started early while in Lithuania religion has maintained its position much longer (Plaat 2003; Vardys 1990). For example, the analysis of Baltic values, based on the World Value Surveys, shows that along the scale which contrasts traditional religious values and secularism, Estonia and Latvia ranked remarkably high in comparative perspective (Taagepera 2002). Against the background of Northern and Western Europe, they reached scores that are slightly below Sweden and West Germany, but comparable with Denmark and Norway. In the context of former state socialism, Estonia and Latvia featured a similar score to the Czech Republic, with only the former East Germany positioned somewhat higher. Lithuania ranked noticeably lower on the traditional vs secular-rational authority scale.

There are reasons to believe that this long-standing cultural difference may relate to the described dissimilarities between the Baltic countries in the gender context as well as in family formation. Pertaining to value change on the global scene, Inglehart and Pippa analysed the association between religion, secularisation and gender equity (2003). Their results demonstrated that the type of religion matters for beliefs about gender equity far more than the strength of religiosity, with the gender equity being generally more advanced in Protestant than in Catholic settings. Among demographers, this divide between denominations, and the role of religiosity in general, is well known as a correlate of fundamental behavioral changes - more secularised populations are likely to shift to new behaviours earlier than their counterparts with stronger adherence to religion. This has been found true for distant as well as more recent transformations of demographic patterns, including the spread of non-marital cohabitation and the disconnection between marriage and childbearing (e.g. Lesthaeghe 1995; Kiernan 2002).

The temporal sequence of demographic development in the Baltic countries seems to fit well the idea of the importance of underlying cultural differences. This holds for the transformation of nuptiality patterns since the 1960s, discussed in the present article, but it is equally applicable to the transition to a modern regime of generation replacement a century earlier (Katus 1994; Plakans 1984). In both cases, the new behavioural patterns emerged earlier in the areas of Estonia and Latvia, followed by Lithuania with a certain time lag. In the given framework, the intermediate position of Latvia with respect to non-marital cohabitation could also be explained by the presence of both Lutheran and Catholic traditions in the modern territory of the country. The role of cultural factors would also help to understand the close synchronism observed in the spread of new family forms since 1960s on the western and eastern shores of the Baltic 
Sea, notwithstanding the diversity of societal regime and institutional frameworks in respective countries.

To conclude, the evidence presented in this paper provides support for the connection between family formation and the gender system in the Baltic countries, but at the same time it is important to be aware that the observed link is not necessarily a causal one. As formulated by Lesthaeghe $(1983 ; 1995)$, these and several other developments can be related to each other as elements of a broader emancipatory process. In the course of this process, the traditional regulatory mechanisms, upheld by religious, communal and family authority, give way to individual freedom of choice and the corresponding exchange patterns. The long-term nature of this process evidently generates continuity or path dependence that explains recurrence of similar sequences of change between the countries in the region.

A final note is that the extensive demographic and societal transformation that has occurred in Estonia, Latvia and Lithuania during the past decade and a half surely calls for the issue to be revisited once the new comparative life history data become available. These data will reveal the extent to which the similarities and dissimilarities observed in this article have persisted into the 21 st century, through the turbulence of regime change in the region.

\section{Acknowledgements}

The article has been prepared in the framework of research theme $0132703 \mathrm{~s} 05$ by the Estonian Ministry of Education and Science and benefited from the support of the Estonian Science Foundation (grant no. 7253). The authors express gratitude to two anonymous reviewers for their comments and Gail Grant for revising the English. We would also like to thank Livia Oláh for her input. 


\section{References}

Aassve A, Billari F, Speder Z (2005). "Societal Transition, Policy Changes and Family Formation." European Journal of Population, 22(1): 127-152.

Avdeev A. (1994). Contraception and Abortions: Trends in the USSR and Prospects for the 1990s. In: Lutz W, Scherbov S, Volkov A, editors. Demographic Trends and Patterns in the Soviet Union Before 1991. London-New York: Routledge: 131146.

Becker G. (1981). The Treatise on the Family. Cambridge (MA): Harvard University Press.

Becker G. (1991). The Treatise on the Family. Enlarged edition. Cambridge (MA): Harvard University Press.

Bernhardt E, Hoem B. (1985). "Cohabitation and Social Background: Trends Observed for Swedish Women Born Between 1936 and 1960." European Journal of Population, 1(4): 375-395.

Billari F. (2006). The Transition to Parenthood in Europe. In: Hantrais L, Philipov D, Billari F. Policy Implications of Changing Family Formation. Population Studies, 49. Strasbourg: Council of Europe Publishing: 63-116.

Billari F, Philipov D. (2003). Mutual Relationships Between Education and Women's Entry into a First Union: the Case of Central and Eastern Europe. In: Kotowska I, Jozwiak J, editors. Population of Central and Eastern Europe. Challenges and Opportunities. Warsaw: Statistical Publishing Establishment: 201-218.

Blom S. (1994). "Marriage and Cohabitation in a Changing Society: Experience of Norwegian Men and Women born in 1945 and 1960." European Journal of Population, 10(2): 143-173.

Blossfeld H-P. (1995). The New Role of Women. Family Formation in Modern Societies. Boulder, San Francisco: Westview Press.

Blossfeld H-P, Huinink J. (1991). "Human Capital Investments or Norms of Role Transitions? How Women's Schooling and Career affect the Process of Family Formation." American Journal of Sociology, 97(2): 143-168.

Blossfeld H-P, Rohwer G. (2002). Techniques of Event History Modeling. New Approaches to Causal Analysis. Mahwav: Lawrence Erlbaum Associates Publishers. 
Blossfeld H-P, Klijzing E, Mills M, Kurz K, editors. (2005). Globalization, Uncertainty and Youth in Society. London and New York: Routledge.

Bracher M, Santow G. (1998). "Economic Independence and Union Formation in Sweden." Population Studies, 43(1): 47-67.

Calot G, Sardon J-P. (1997). "Etonnante Fécontité Suédoise." Futuribles, 217: 5-14.

Cherlin A. (1992). Marriage, Divorce, Remarriage. Revised and Enlarged Edition. Cambridge (MA): Harvard University Press.

Chesnais J-C. (1996). "Fertility, Family and Social Policy in Contemporary Western Europe." Population and Development Review, 22(4): 729-739.

Cigno, A. (1991). Economics of the Family. Oxford: Oxford University Press.

Coale A, Anderson B, Härm, E. (1979). Human Fertility in Russia since the Nineteenth Century. Princeton: Princeton University Press.

Coale A, Watkins S, editors. (1986). The Decline of Fertility in Europe. Princeton: Princeton University Press.

Corijn M, Klijzing E, editors (2001). Transition to Adulthood in Europe. Dordrect: Kluwer Academic Publishers.

Council of Europe. (2006). Recent Demographic Developments in Europe. Strasbourg: Council of Europe Publishing.

David H, editor. (1999). From Abortion to Contraception. A Resource to Public Policies and Reproductive Behaviour in Central and Eastern Europe from 1917 to the Present. Westport, Connecticut: Greenwood Press.

Davis K. (1984). "Wives and Work: the Sex-role Revolution and its Consequences." Population and Development Review, 10(3): 397-417.

Ermisch J. (1996). The Economic Environment and Family Formation. In: Coleman D, editor. Europe's Population in the 1990s. New York: Oxford University Press: 144-162.

European Commission (2006). Employment in Europe: Recent Trends and Prospects. Luxembourg: Office for Official Publications of the European Communities.

Festy P. (1984). Fertility in Western Countries from 1870 to 1970. Bangkok, United Nations.

Festy P, Prioux F. (2002). An Evaluation of the FFS project. New York and Geneva: United Nations. 
Goldscheider F, Waite L. (1986). "Sex Differences in the Entry into Marriage." American Journal of Sociology, 92(1): 91-109.

Gustafsson S, Kalwij, A, editors. (2006). Education and Postponement of Maternity. Springer.

Hajnal J. (1965). European Marriage Patterns in Perspective. In: Hajnal, J, Glass D, Eversley, D, editors. Population in History. Essays in Historical Demography. Chicago: Alding Publishing Company: 101-143.

Hoem J. (1986). "The Impact of Education on Modern Family-union Initiation." European Journal of Population, 2(2): 113-133.

Hoem J, Rennermalm B. (1985). "Modern Family Initiation in Sweden: Experience of Women Born between 1936 and 1960." European Journal of Population, 1(1): $81-112$.

Hoehn C, Avramov D, Kotowska I. (2008). People, Population Change and Policies. Lessons from Population Policy Acceptance Study. Springer. Forthcoming.

Inglehart R, Pippa, N. (2003). Rising Tide: Gender Equality and Cultural Change around the world. Cambridge: Cambridge University Press.

Kahk J, Tarvel E. (1997). An Economic History of the Baltic countries. Acta Universitatis Stockholmiensis, Studia Baltica Stockholmiensia, 20. Stockholm: Almquist and Wiksell International.

Kantorova V. (2004). Family Life Transitions of Young Women in a Changing Society: First Union Formation and Birth of First Child in the Czech Republic, 19701997. Prague: Charles University.

Kantorova V. (2006). Education and Entry into Motherhood in the Czech Republic during State-Socialism and the Transition Period, 1970-1997. In: Gustafsson S, Kalwij, A, editors. Education and Postponement of Maternity. Springer: 237258.

Katus K. (1994). Fertility Transition in Estonia, Latvia and Lithuania. In: Lutz W, Scherbov S, Volkov A, editors. Demographic Trends and Patterns in the Soviet Union before 1991. London and New York, Routledge: 89-111.

Katus K. (1997). "Long-term Fertility Development in Baltoscandia." Yearbook of Population Research in Finland, 34: 18-35. 
Katus K. (2003). Non-marital Fertility in the Baltic region. In: Katus K, Puur A, editors. Unity and Diversity of Population Development: Baltic and South Caucasian regions. RU Series D, 3. Tallinn: EKDK: 207-224.

Katus K, Puur A, Põldma A. (2002). Eesti põlvkondlik rahvastikuareng. [Cohort Population Development in Estonia] RU Series D, 2. Tallinn: EKDK.

Katus K, Puur A, Põldma A. (2004). "Population-related Policies in Estonia during the 20th Centrury: Stages and Turning Points." Yearbook of Population Research in Finland, 40: 73-104.

Katus K, Puur A, Sakkeus L. (2005). Immigrant Population in Estonia. In: Haug W, Compton P, Courbage Y, editors. The Demographic Characteristics of Immigrant Populations. Strasbourg: Council of Europe Publishing: 131-192.

Katus K, Puur A, Sakkeus L. (2005). Transition to adulthood in Estonia. Evidence from the FFS. In: Blossfeld H-P, Klijzing E, Mills M, Kurz K, editors. Globalization, Uncertainty and Youth in Society. London and New York: Routledge: 215-248.

Kelam A. (1986). The Family in Soviet Estonia: a Sociological Portrait. Tallinn: Perioodika.

Kiernan K. (2002). The State of European Unions: an Analysis of Partnership Formation and Dissolution. In: Macura M, Beets G, editors. Dynamics of Fertility and Partnership in Europe. Proceedings of the Family and Fertility Surveys Flagship Conference, 1. New York and Geneva: United Nations: 57-76.

Klijzing E, Cairns H. (2000). On the Quality of the FFS Event History Data: of Critical Importance in the Life Course Research. Globalife WP, 13. Bielefeld: University of Bielefeld.

Kreyenfeld M. (2006). Family Formation in East and West Germany before and after Unification. In: Gustafsson S, Kalwij, A, editors. Education and Postponement of Maternity. Springer: 225-236.

Lesthaeghe R. (1983). "A Century of Demographic and Cultural Change in Western Europe: an Exploration of Underlying Dimensions." Population and Development Review, 9(3:) 411-435.

Lesthaeghe R. (1995). The Second Demographic Transition in Western Countries: an Interpretation. In: Mason K, Jensen, A-M, editors. Gender and Family Change in Industrialised Countries. Oxford: Clarendon Press: 17-62.

Lesthaeghe R, editor. (2002). Meaning and Choice - Value Orientations and Life Course Decisions. The Hague: NIDI. 
Lesthaeghe R, Moors G. (1996). Living Arrangements, Socio-Economic Position, and Values Among Young Adults: A Pattern Description for France, West Germany, Belgium and Netherlands. In: Coleman D, editor. Europe's Population in the 1990s. New York: Oxford University Press: 163-221.

Lesthaeghe R, Surkyn J. (2002). "New Forms of Household Formation in Central and Eastern Europe: Are They Related to Newly Emerging Value Orientations." Economic Survey of Europe, 2002(1): 197-216.

Lesthaeghe R, Van de Kaa D.J. (1986). Twee demografische transities? In: Lesthaeghe R, Van de Kaa D.J., editors.Bevolkning: groei end krimp. Deventer: Van Loghum Slaterus: 9-24.

Liefbroer A. (1991). "The Choice Between a Married or Unmarried Cohabitation. A Competing Risk Analysis." European Journal of Population, 7(3): 273-298.

Liefbroer A, Corijn M. (1999). "Who, what, where and when? Specifying the Impact of Educational Attainment and Labour Force Participation on Family Formation." European Journal of Population, 15(1): 45-75.

Lugus O, Vartia P, editors. (1993). Estonia and Finland: a Retrospective Socioeconomic Comparison. Helsinki: Taloustieto.

Manting D. (1994). Dynamics in Marriage and Cohabitation. an Intertemporal Life Course Analysis of First Union Formation and Dissolution. Amsterdam: Thesis Publishers.

Mason K, Jensen A-M, editors. (1995). Gender and Family Change in Industrialised Countries. Oxford: Clarendon Press.

Mason K (1997). "Explaining Fertility Transitions." Demography, 34(4): 443-454.

Mason K (2001). "Gender and Family Systems in the Fertility Transitions." Population and Development Review, 27(Supplement): 160-176.

McDonald P. (2000). "Gender Equity in Theories of Fertility Transition." Population and Development Review, 26(3): 427-440.

McDonald P. (2002). "Sustaining Fertility through Public Policy: The Range of Options." Population-E, 57(3): 417-446.

Mellens M. (1999). Determinants of Demographic Behaviour. In: de Beer J, van Wissen L, editors. Europe: One continent, Different Worlds. Population scenarios for the 21st century. Dordrecht: Kluwer Academic Publishers. 
Mertelsmann O, editor. (2003). The Sovietisation of the Baltic States 1940-1956. Tartu: Kleio.

Mills M. (2000). The Transformation of Partnerships. Canada, the Netherlands and the Russian Federation in the Age of modernity. Amsterdam: Thela Thesis.

Misiunas R, Taagepera R. (1993). The Baltic States. Years of Dependence 1940-1990. London, Hurst and Berkeley: California University Press.

Mitchell B. (2003). International Historical Statistics. Europe 1750-2000. Basingstoke: New York, Palgrave Macmillan.

Nazio T, Blossfeld H-P. (2003). "The Diffusion of Cohabitation among Young Women in West Germany, East Germany and Italy." European Journal of Population, 19(1): 47-82.

Ni Brolchain M. (1993). East-West Marriage Contrasts, Old and New. In: Blum A, Rallu J, editors. European Population. Demographic Dynamics. Paris: John Libbey Eurotext: 461-479.

Noorkõiv, R, Orazem P, Puur A, Vodopivec M. (1998). "Employment and Wages Dynamics in Estonian Transition." Economics of Transition, 6(2): 481-503.

Olah L, Fratczak E. (2003). Gendering Family Formation. First marriage and First birth in Hungary and Poland. In: Kotowska I, Jozwiak J, editors. Population of Central and Eastern Europe. Challenges and Opportunities. Warsaw: Statistical Publishing Establishment: 219-250.

Ono H. (2003). "Women's Economic Standing, Marriage Timing and Cross-national Contexts of Gender." Journal of Marriage and the Family, 65(2), 275-286.

Oppenheimer V. (1988). "A Theory of Marriage Timing." American Journal of Sociology, 94(3): 563-591.

Oppenheimer V. (1994). "Women's Rising Employment and the Future of the Family in Industrial Societies." Population and Development Review, 20(2): 293-342.

Palli H. (2004). Traditional Reproduction of the Population in Estonia in the 17th and 18th Centuries. RU Series D, 4. Tallinn: EKDK.

Pinelli A, Hoffman-Nowotny H-J, Fux B. (2001). Fertility and New Types of Households and Family Formation in Europe. Strasbourg: Council of Europe Publishers.

Plaat J. (2003). "Religious Change in Estonia and the Baltic States during the Soviet Period in Comparative Perspective." Journal of Baltic Studies, 34(1): 52-73. 
Plakans A. (1984). "The Demographic Transition in the Baltic Provinces and Finland: Prospects for A Comparative Study." Journal of Baltic Studies, 15(2/3): 171184.

Pott-Buter H. (1993). Facts and Fairy Tales about Female Labour, Family and Fertility: a Seven Country Comparison 1850-1990. Amsterdam: Amsterdam University Press.

Puur A. (1995). Labour Force Participation Trends in the Baltic states 1959-1989. Lundh C, editor. Demography, Economy and Welfare. Scandinavian Population Studies, 10: 321-335. Lund: Lund University Press.

Puur A. (2000). Female Labour Force Participation During Economic Transition: the Case of Estonia. RU Series B, 44. Tallinn: EKDK.

Rao V. (1990). "Marriage Risks, Cohabitation and Premarital Births in Canada." European Journal of Population, 6(1): 27-49.

Rauch, G. (1974). The Baltic States: the Years of Independence. London, Hurst and Berkeley: California University Press.

Rei A. (1970). The Drama of Baltic Peoples. Second edition. Stockholm: Vaba Eesti.

Robert P, Bukodi E. (2005). The Effects of Globalisation Process on the Transition to Adulthood in Hungary. In: Blossfeld H-P, Klijzing E, Mills M, Kurz K, editors. Globalization, Uncertainty and Youth in Society. London and New York: Routledge: 177-214.

Sakkeus L. (2000). "Demographic Behaviour Patterns of Immigrants and National Minority of the Same Ethnic Background: the Case of Estonia." Trames, 4(3): 268-285.

Sakkeus L. (2003). Migration Trends in the Baltic states 1945-1991. In: Katus K, Puur A, editors. Unity and Diversity of Population Development: Baltic and South Caucasian Regions. RU Series D, 3. Tallinn: EKDK: 253-278.

Santow G, Bracher M. (1994). "Change and Continuity in the Formation of First Marital Unions in Australia." Population Studies, 48: 475-496.

Santow G, Bracher M. (1997). Whither Marriage? Trends, Correlates and Interpretations. International Population Conference, Beijing. Vol.2. Liege, IUSSP: 919-939. 
Sardon, J-P, Calot, G. (1997). Le Reprise de la Fécontité au Milieu des Années Trente, Phénomene non Percu des Observateurs du Temps. Saint-Germain-en-Laye: Observatoire Démographique Européen.

Sklar J. (1974). "The Role of Marriage Behaviour in the Demographic Transition: the Case of Eastern Europe around 1900." Population Studies, 28(2): 231-248.

Speder Z. (2005). "The Rise of Cohabitation as First Union and Some Neglected Factors of Recent Demographic Developments in Hungary." Demografia. English Edition, 48: 77-103.

Stankuniene V. (1991). Ways of Taking Care of Pre-school Children in Lithuania. Paper to European Population Conference. Paris.

Stankuniene V. (1997). Transformation of Lithuanian Family: A Turning Point or Deformations of Traditional Features. In: Katus K, Stankuniene V, Vikat A, editors. Demographic Development in Baltic Countries. Special Issue of Revue Baltique. Vilnius: 64-77.

Stankuniene V, Jonkaryte A, Mikulioniene S, Mitrikas A, Maslauskaite A. (2003). Seimos revoliucija? Issukiai seimos politikai. Vilnius: Socialniu Tyrimu Institutas.

Taagepera R. (2002) "Baltic Values and Corruption in Comparative Context." Journal of Baltic Studies, 33(3): 243-258.

UNECE (1998). Fertility and Family Surveys in Countries of the ECE region. Standard country report. Latvia. New York and Geneva: United Nations.

UNECE (2000a). Fertility and Family Surveys in Countries of the ECE region. Standard country report. Estonia. New York and Geneva: United Nations.

UNECE (2000b). Fertility and Family Surveys in Countries of the ECE region. Standard country report. Lithuania. New York and Geneva: United Nations.

UNICEF (1999). Women in Transition. Regional Monitoring Report, 6. Florence: UNICEF International Child Development Centre.

Van de Kaa D.J. (1987). "Europe's Second Demographic Transition." Population Bulletin, 42(1).

Valge J. (2003). Lahtirakendamine. Eesti Vabariigi majanduse stabiliseerimine 19181924. [Stabilisation of Estonian Economy 1918-1924] Tallinn: Rahvusarhiiv.

Vardys V. (1990). The Role of the Churches in the Maintenance of Regional and National Identity in the Baltic Republics. In: Loeber D, Vardys V, Kitching L, 
editors. Regional Identity under Soviet Rule: The Case of the Baltic States. Hackettstown: 151-164.

Vikat A. (1994). Family Formation in Estonia. Publications of the Finnish Demographic Society, no.15. Helsinki.

Vikat A. (1997). Recent Trends in Partnership Formation and Dissolution in Estonia. In: Katus K, Stankuniene V, Vikat A, editors. Demographic Development in Baltic Countries. Special issue of Revue Baltique. Vilnius: 78-89.

Waite L, Spitze G. (1981). "Young Women's Transition to Marriage." Demography, 18(4): 681-694.

Zvidrinsh P. (1995) Recent Changes in the Ethnic Structure in the Baltic states. In: Lundh C, editors. Demography, Economy and Welfare. Scandinavian Population Studies, 10. Lund: Lund University Press: 336-351.

Zvidrins P, Ezera L. (1999). "Dynamics and Differentiation of Cohabitation in Latvia." Revue Baltique, 13: 71-81. 


\section{Appendix}

Table 1A: Distribution of respondents (exposure time) at the levels of covariates

\begin{tabular}{|c|c|c|c|c|c|c|}
\hline & \multicolumn{2}{|c|}{ Estonia } & \multirow{2}{*}{$\frac{\text { Latvia }}{\text { Men }}$} & \multicolumn{3}{|c|}{ Lithuania } \\
\hline & Men & Women & & Women & Men & Women \\
\hline \multicolumn{7}{|l|}{ Educational attainment } \\
\hline Low & 24.7 & 9.8 & 14.1 & 6.2 & 8.0 & 4.8 \\
\hline Medium & 56.7 & 65.7 & 67.2 & 64.8 & 65.3 & 60.4 \\
\hline High & 18.6 & 24.5 & 18.7 & 29.0 & 26.7 & 34.8 \\
\hline \multicolumn{7}{|l|}{ Activity status ${ }^{a}$} \\
\hline Enrolled in education & 33.4 & 51.0 & 35.3 & 48.0 & 34.5 & 51.6 \\
\hline Non-employed & 22.0 & 7.6 & 14.2 & 6.3 & 17.5 & 8.2 \\
\hline Employed & 44.6 & 41.4 & 50.5 & 45.7 & 48.0 & 40.2 \\
\hline \multicolumn{7}{|l|}{ Birth cohort } \\
\hline $1944-1948$ & 17.7 & 19.8 & 9.5 & 9.2 & 10.9 & 8.8 \\
\hline $1949-1953$ & 18.2 & 16.5 & 15.9 & 16.6 & 14.8 & 15.6 \\
\hline 1954-1958 & 16.0 & 18.1 & 18.4 & 18.8 & 18.0 & 17.0 \\
\hline $1959-1963$ & 15.3 & 16.4 & 17.8 & 21.9 & 18.5 & 19.2 \\
\hline 1964-1968 & 17.0 & 16.9 & 17.8 & 13 & 18.8 & 16.6 \\
\hline $1969-1973$ & 15.8 & 12.3 & 15.0 & 14.9 & 13.1 & 14.5 \\
\hline $1974-1977$ & & & 5.6 & 5.6 & 5.9 & 8.3 \\
\hline \multicolumn{7}{|l|}{ Region of origin } \\
\hline Urban & 52.0 & 54.0 & 54.6 & 54.1 & 55.5 & 55.7 \\
\hline Rural & 48.0 & 46.0 & 45.4 & 45.9 & 44.5 & 44.3 \\
\hline \multicolumn{7}{|l|}{ Family of origin } \\
\hline Two-parent family & 79.0 & 80.9 & 82.6 & 82.4 & 84.8 & 85.7 \\
\hline Single-parent family & 21.0 & 19.1 & 17.4 & 17.6 & 15.2 & 14.3 \\
\hline \multicolumn{7}{|l|}{ Number of siblings } \\
\hline None & 16.4 & 13.5 & 17.0 & 20.4 & 12.3 & 12.2 \\
\hline 1 or 2 & 42.9 & 40.5 & 45.0 & 42.2 & 39.7 & 38.8 \\
\hline 3 or more & 40.7 & 46.0 & 38.0 & 37.4 & 48.0 & 49.0 \\
\hline
\end{tabular}


Katus et al.: First union formationin Estonia, Latvia, and Lithuania

Table 1A: (continued)

\begin{tabular}{|c|c|c|c|c|c|c|}
\hline & \multicolumn{2}{|c|}{ Estonia } & \multicolumn{2}{|c|}{ Latvia } & \multicolumn{2}{|c|}{ Lithuania } \\
\hline & Men & Women & Men & Women & Men & Women \\
\hline \multicolumn{7}{|l|}{ Religious } \\
\hline Yes b & 5.1 & 6.8 & 12.8 & 20.3 & 49.0 & 63.1 \\
\hline No & 94.9 & 93.2 & 87.2 & 79.7 & 51.0 & 36.9 \\
\hline \multicolumn{7}{|l|}{ Left parental home $^{a}$} \\
\hline Yes $^{C}$ & 38.6 & 21.5 & 12.8 & 19.5 & 35.4 & 30.3 \\
\hline No & 61.4 & 78.5 & 87.2 & 80.5 & 64.6 & 69.7 \\
\hline \multicolumn{7}{|l|}{$\begin{array}{l}\text { Pre-union } \\
\text { pregnancy/child }^{\text {a }}\end{array}$} \\
\hline None & 97.8 & 94.8 & 97.9 & 94.8 & 97.6 & 96.3 \\
\hline Pregnancy & 1.1 & 1.7 & 1.5 & 2.5 & 1.4 & 1.8 \\
\hline Child under 1 year & 0.3 & 0.9 & 0.3 & 0.9 & 0.4 & 0.6 \\
\hline Child 1-2 years & 0.4 & 1.2 & 0.2 & 0.9 & 0.3 & 0.6 \\
\hline Child $3+$ years & 0.4 & 1.4 & 0.1 & 0.9 & 0.3 & 0.7 \\
\hline
\end{tabular}

a Time-varying covariates; ${ }^{b}$ Based on V916 (SRF); ${ }^{c}$ Lived independently for at least 6 months. 
Table 2A: Relative risks of starting first union for control characteristics, final model

\begin{tabular}{|c|c|c|c|c|c|c|}
\hline & Estonia & & Latvia & & Lithuan & \\
\hline & Men & Women & Men & Women & Men & Women \\
\hline Birth cohort & & & & & & \\
\hline $1944-1948^{a}$ & 1.00 & 1.00 & 1.00 & 1.00 & 1.00 & 1.00 \\
\hline $1949-1953$ & 1.06 & $1.19^{* *}$ & 0.93 & 0.95 & 1.02 & $0.85^{*}$ \\
\hline 1954-1958 & $1.36^{* * *}$ & 1.13 & 1.21 & 1.01 & 1.08 & 0.99 \\
\hline $1959-1963$ & $1.45^{\star \star \star}$ & $1.38^{* * *}$ & 1.24 & 1.01 & 1.02 & 0.93 \\
\hline 1964-1968 & $1.34^{\star *}$ & $1.35^{* * *}$ & $1.39^{* *}$ & 1.11 & 1.12 & 0.97 \\
\hline $1969-1973$ & 1.21 & $1.78^{* \star *}$ & 1.24 & 1.00 & $1.54^{\star * *}$ & 1.15 \\
\hline $1974-1977$ & - & - & 0.77 & 1.22 & $1.56^{*}$ & $1.39^{* *}$ \\
\hline Region of origin & & & & & & \\
\hline Urban $^{a}$ & 1.00 & 1.00 & 1.00 & 1.00 & 1.00 & 1.00 \\
\hline Rural & 0.90 & 0.92 & $0.84^{* *}$ & 0.95 & 0.97 & $0.87^{\star * *}$ \\
\hline Family of origin & & & & & & \\
\hline Two-parent family ${ }^{a}$ & 1.00 & 1.00 & 1.00 & 1.00 & 1.00 & 1.00 \\
\hline Single-parent family & 1.08 & $1.11^{*}$ & $1.30^{* * *}$ & 1.02 & 1.04 & 1.06 \\
\hline Number of siblings & & & & & & \\
\hline None & $0.79^{* *}$ & 1.02 & 1.11 & 0.89 & $1.20^{*}$ & 0.96 \\
\hline 1 or $2^{a}$ & 1.00 & 1.00 & 1.00 & 1.00 & 1.00 & 1.00 \\
\hline 3 or more & 1.12 & 1.03 & 0.90 & $0.88^{*}$ & $1.12^{*}$ & 1.05 \\
\hline Religious & & & & & & \\
\hline Yes & 0.84 & 1.02 & $1.27^{\star *}$ & 0.92 & $1.12^{*}$ & 0.93 \\
\hline $\mathrm{No}^{\mathrm{a}}$ & 1.00 & 1.00 & 1.00 & 1.00 & 1.00 & 1.00 \\
\hline Left parental home & & & & & & \\
\hline Yes & 1.13 & $0.89^{*}$ & $1.32^{* \star *}$ & $1.21^{\star \star *}$ & $1.19^{\star * *}$ & $1.17^{\star * \star}$ \\
\hline $\mathrm{No}^{\mathrm{a}}$ & 1.00 & 1.00 & 1.00 & 1.00 & 1.00 & 1.00 \\
\hline
\end{tabular}


Katus et al.: First union formationin Estonia, Latvia, and Lithuania

Table 2A: (continued)

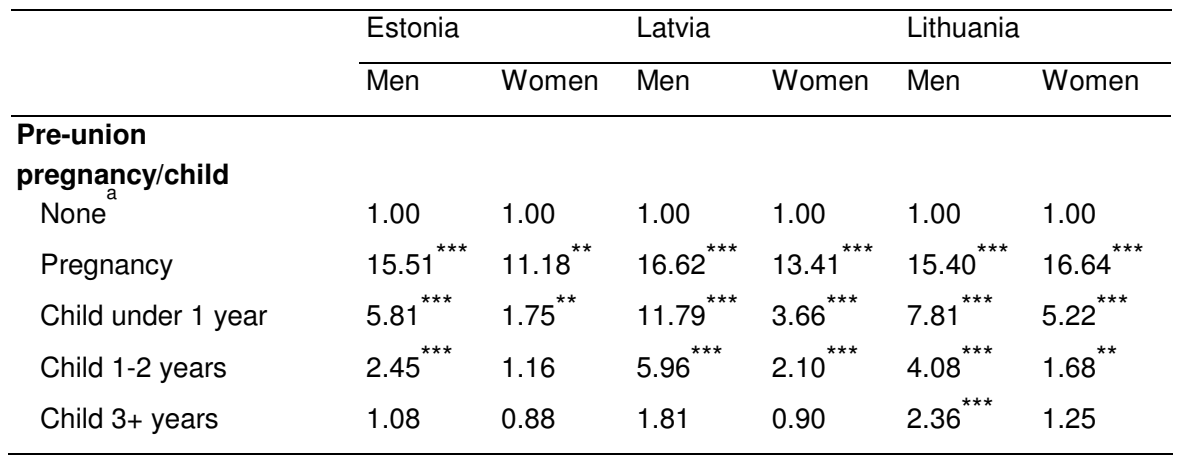

${ }^{* \star *} p<0.01,{ }^{* *} p<0.05,{ }^{*} p<0.1 ;{ }^{\text {a Reference category }}$ 